THIAGO BALDANI GOMES DE FILIPPO

PROPORCIONALIDADE LEGISLATIVA PENAL: PROPOSTAS PARA O APERFEIÇOAMENTO DOS TIPOS E PARA O EQUILÍBRIO ENTRE AS SANÇÕES DO DIREITO PENAL BRASILEIRO

Tese de Doutorado

Orientadora: Professora Titular Ana Elisa Liberatore Silva Bechara

UNIVERSIDADE DE SÃO PAULO

FACULDADE DE DIREITO

São Paulo-SP

2020 


\section{PROPORCIONALIDADE LEGISLATIVA PENAL: PROPOSTAS PARA O APERFEIÇOAMENTO DOS TIPOS E PARA O EQUILÍBRIO ENTRE AS SANÇÕES DO DIREITO PENAL BRASILEIRO}

Tese apresentada à Banca Examinadora do Programa de Pós-graduação em Direito da Faculdade de Direito da Universidade de São Paulo, como exigência parcial para a obtenção do título de Doutor em Direito, na área de concentração de Direito Penal, Medicina Forense e Criminologia, sob a orientação da Professora Titular Ana Elisa Liberatore Silva Bechara

UNIVERSIDADE DE SÃO PAULO

FACULDADE DE DIREITO

São Paulo-SP

2020 
Serviço de Processos Técnicos da Biblioteca da Faculdade de Direito da Universidade de São Paulo

De Filippo, Thiago Baldani Gomes

Proporcionalidade Legislativa penal: propostas para o aperfeiçoamento dos tipos e para o equilíbrio entre as sanções do direito penal brasileiro.

São Paulo: T. B. G. De Filippo, 2020.

$302 \mathrm{f} . . ; 30 \mathrm{~cm}$.

Tese (Doutorado) - Universidade de São Paulo, 2020.

Orientadora: Professora Ana Elisa Liberatore Silva Bechara

Notas de rodapé.

Inclui bibliografia.

1. direito penal. 2. proporcionalidade. 3. bem jurídico. 4. ofensividade. 5. sanções penais abstratas. I. Bechara, Ana Elisa Liberatore Silva. II. Título. 


\section{THIAGO BALDANI GOMES DE FILIPPO}

\section{PROPORCIONALIDADE LEGISLATIVA PENAL: PROPOSTAS PARA O APERFEIÇOAMENTO DOS TIPOS E PARA O EQUILÍBRIO ENTRE AS SANÇÕES DO DIREITO PENAL BRASILEIRO}

Tese apresentada à Banca Examinadora do Programa de Pós-graduação em Direito da Faculdade de Direito da Universidade de São Paulo, como exigência parcial para a obtenção do título de Doutor em Direito, na área de concentração de Direito Penal, Medicina Forense e Criminologia, sob a orientação da Professora Titular Ana Elisa Liberatore Silva Bechara.

\section{BANCA EXAMINADORA}

Presidente:

Prof ${ }^{a}$. Titular Ana Elisa Liberatore Silva Bechara

$1^{0}$ Examinador(a)

$2^{\circ}$ Examinador(a):

$3^{\circ}$ Examinador(a):

$4^{\circ}$ Examinador(a):

$5^{\circ}$ Examinador(a): 
À Juliana, à Bia e ao Rafa, que são as melhores partes de mim. 


\section{AGRADECIMENTOS}

À Professora Ana Elisa Liberatore Silva Bechara, por sua excelência e dedicação pela docência, profissional que muito admiro e por quem tive a honra de ser orientado durante este trabalho, um sincero agradecimento por acreditar em meu projeto de pesquisa e confiar nos seus frutos.

Aos Professores Renato de Mello Jorge Silveira e Eduardo Viana, pelas imprescindíveis observações no Exame de Qualificação, que também serviram de grande estímulo para prosseguir.

Aos Professores Alamiro Velludo Salvador Netto, Ana Elisa Liberatore Silva Bechara, Celso Fernandes Campilongo, Floriano de Azevedo Marques Neto, Helena Regina Lobo da Costa, Luciano Anderson de Souza, Mariângela Gama de Magalhães Gomes e Renato de Mello Jorge Silveira, pelo esmero com que ministraram as disciplinas cursadas, cujos ensinamentos foram essenciais para a elaboração da tese.

Aos funcionários da biblioteca da USP e do IBCCRIM, que sempre me atenderam gentilmente, dispondo-se com muita atenção a quaisquer solicitações.

Aos meus pais, Teodoro e Débora, à minha avó Gessy e a todos os demais familiares queridos, pelo constante afeto.

À Juliana, à Bia e ao Rafa, pelo grande amor e pela compreensão das horas que lhe foram subtraídas.

A Deus, pelo dom da vida. 
"Mas a verdade é que não só nos países autocráticos, como naqueles supostamente livres como a Inglaterra, a América, a França e outros - as leis não foram feitas para atender à vontade da maioria, mas sim à vontade daqueles que detêm o poder."

Lev Tolstói

"As leis inúteis enfraquecem as leis necessárias." Luc de Clapiers Vauvenargues 
DE FILIPPO, Thiago Baldani Gomes. Proporcionalidade legislativa penal: propostas para o aperfeiçoamento dos tipos e para o equilíbrio entre as sanções do direito penal brasileiro. 2020. 302 f. Tese (Doutorado). Faculdade de Direito, Universidade de São Paulo, São Paulo, 2020

\section{RESUMO}

O presente trabalho tem por objetivo estabelecer uma teoria da proporcionalidade legislativa penal a partir da integração à estrutura do princípio da proporcionalidade dos standards materiais do Direito dos Estados Unidos. Inicialmente, analisa-se as multifacetadas repercussões do fenômeno da pós-modernidade à legislação penal, a partir de questões espistemológicas, político-econômicas e sociológicas. Em seguida, a partir da constatação da hipertrofia da legislação penal brasileira, trata de analisar manifestações da tutela penal inadequada, da tutela penal desnecessária e da tutela penal estritamente desproporcional. Após, passa-se a tecer considerações sobre os princípios da proporcionalidade e da razoabilidade, observando-se algumas propostas de concretização da proporcionalidade no âmbito penal para se concluir, preliminarmente, acerca da viabilidade de integração dos elementos da proporcionalidade à ideia sujacente aos testes de constitucionalidade. Ao final, propõe-se uma teoria da proporcionalidade legislativa penal que congregue critérios de justiça material como a proteção de bens jurídicos, a ofensividade e equilíbrio entre as penas no interior da adequação, da necessidade e da proporcionalidade em sentido estrito e, ao mesmo tempo, seja apta a operar-lhes certa flexibilidade, a depender do interesse a ser protegido, da forma de proteção e dos patamares sancionatórios abstratos.

Palavras-chave: proporcionalidade legislativa - testes de constitucionalidade - bens jurídicos - ofensividade - equilíbrio entre penas. 
DE FILIPPO, Thiago Baldani Gomes. Proportionality of the criminal statute-laws: proposals for the improvement of the criminal statutes and for the balance between the sanctions of the brazilian criminal law. 2020. 302 f. Thesis (Doctorate). Faculty of Law, University of São Paulo, São Paulo, 2020.

\begin{abstract}
This present paperwork has as its objective establishing a theory of proportionality of the criminal statute-laws, starting from the integration between the principle of proportionality's structure and the material standards from the United States Law. Initially, it will be analyzed the multifaceted repercussions concerning the post-modernity phenomenon linked to the criminal statutes, from epistemological, political-economic and sociological issues. As it follows, from the finding of Brazilian criminal statutes' hypertrophy, it will discourse about the manifestations of the inadequate criminal protections, the unnecessary criminal protections and the strictly disproportionate criminal protections. After, there will be some considerations regarding the principles of proportionaly and reasonability, observing some proposals aiming is embodiment on the criminal field and preliminarily concluding for the viability of an integration between the proportionality elements and the idea underlying the constitutional tests. At the end, it proposes a theory of the proportionality of the criminal statute-laws, able to congregate material justices criteria as the protection of legal goods, harmfulness and statute sanctioning balances at the core of the adequacy, necessity and strict proportionality and, at the same time, be apt to operate relative flexibility, depending on the interest to be protected, how it is protected and the abstract sanctioning levels.
\end{abstract}

Keywords: legislative proportionality - constitutionality tests - legal goods - harmfulness - statute sanctioning balances. 
DE FILIPPO, Thiago Baldani Gomes. Proporcionalidad legislativa penal: propuestas para la mejora de tipos y para el equilibrio entre las sanciones del derecho penal brasileño. 2020. 302 f. Tesis (Doctorado). Facultad de Derecho, Universidad de São Paulo, São Paulo, 2020.

\section{RESUMEN}

Este documento pretende establecer una teoría de la proporcionalidad legislativa penal a partir de la integración en la estructura del principio de proporcionalidad de las normas materiales de la ley de los Estados Unidos. Inicialmente, analizamos las repercusiones multifacéticas del fenómeno de la posmodernidad en la legislación penal, sobre la base de cuestiones espistemológicas, político-económicas y sociológicas. Luego, a partir de la observación de la hipertrofia del derecho penal brasileño, trata de analizar las manifestaciones de protección penal inadecuada, protección penal innecesaria y protección penal estrictamente desproporcionada. Posteriormente, se hacen consideraciones sobre los principios de proporcionalidad y razonabilidad, observando algunas propuestas para la realización de la proporcionalidad en el ámbito penal para concluir, preliminarmente, sobre la factibilidad de integrar los elementos de proporcionalidad con la idea subyacente a las pruebas de constitucionalidad. Al final, se propone una teoría de proporcionalidad legislativa penal que reúne criterios de justicia material como la protección de bienes jurídicos, la ofensividad y el equilibrio entre sanciones dentro de la adecuación, la necesidad y la proporcionalidad en el sentido estricto y al mismo tiempo. Poder operar una cierta flexibilidad, dependiendo del interés a proteger, la forma de protección y los niveles de sanciones abstractas.

Palabras clave: proporcionalidad legislativa - pruebas de constitucionalidad - bienes jurídicos - ofensividad - niveles de sanciones abstractas. 


\section{SUMÁRIO}

Introdução

1. Dilemas contemporâneos acerca da desproporcionalidade das leis penais e suas influências no cenário nacional.

1.1. As transformações do Direito Penal brasileiro decorrentes do contexto pósmoderno

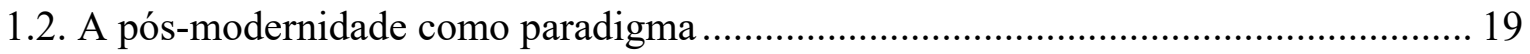

1.3. Base epistemológica: a opacidade das ciências sociais clássicas ................................ 23

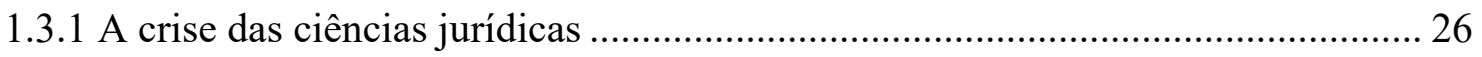

1.3.2. O desapego pela dogmática em busca da eficiência punitiva ............................. 29

1.4. Base político-econômica: esvaziamento da soberania estatal pela globalização.......... 38

1.4.1. A internacionalização do Direito Penal.................................................................. 44

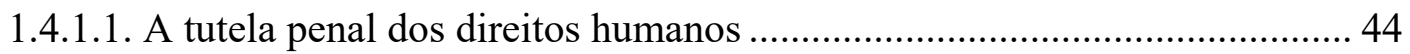

1.4.1.2. O discurso hegemônico da insegurança social......................................... 49

1.4.1.3. A tutela penal de interesses econômicos ....................................................... 56

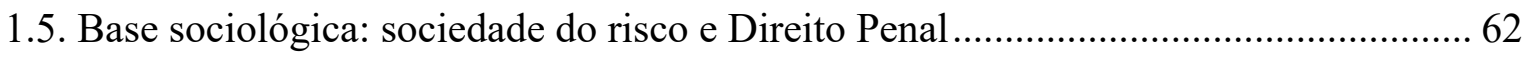

2. Manifestações de desproporcionalidades das leis penais brasileiras ...................... 77

2.1. A hipertrofia como marca da desproporcionalidade penal: a primazia da emergência e seus efeitos meramente simbólicos ....................................................... 77

2.2. Modalidades de desproporcionalidades da tutela penal.......................................... 86

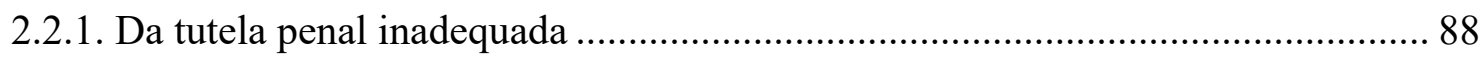

2.2.1.1. Inadequação da tutela penal de moralidades.............................................. 97

2.2.1.2. Inadequação e tutela penal de interesses abstratos................................... 103

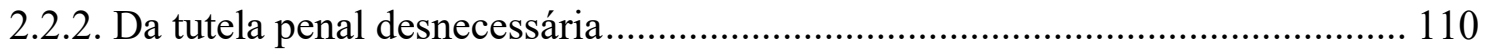

2.2.2.1. Tutela desnecessária e tipos de perigo abstrato ..................................... 117

2.2.2.1.1. Crimes de ação concretamente perigosa ................................. 122

2.2.2.1.2. Crimes de acumulação ......................................................... 126

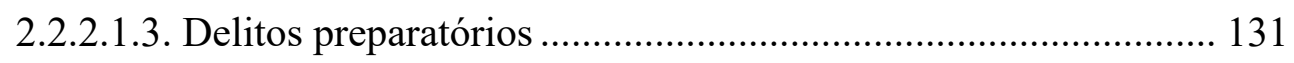

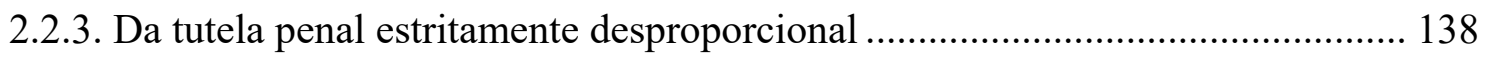

2.2.3.1. Desproporcionalidades estritas e natureza de bens jurídicos .................. 149

2.2.3.2. Desproporcionalidades estritas e desvalores abstratos das condutas ....... 153

2.2.3.3. Desproporcionalidades estritas e desvalores abstratos dos resultados..... 155 
3.1. Considerações acerca de uma necessária aproximação entre Direito Penal e Constituição

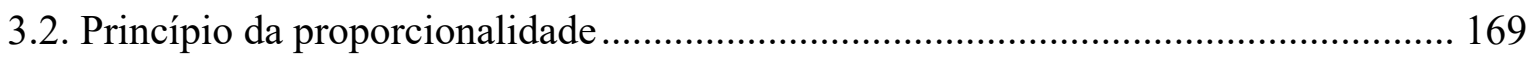

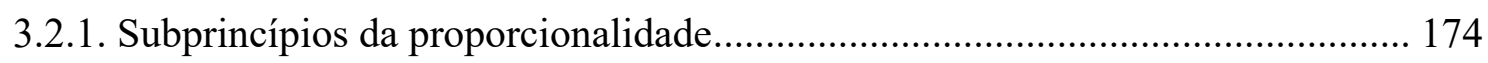

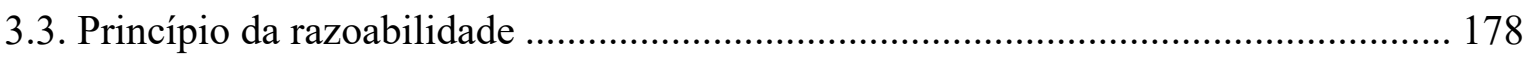

3.3.1. Os standards materiais do Direito Constitucional dos Estados Unidos.

3.4. Questões acerca do rendimento da proporcionalidade como critério limitador da intervenção penal

3.5. Algumas propostas de concretização dos elementos da proporcionalidade no âmbito penal.

3.6. A concretização dos elementos da proporcionalidade em matéria penal por meio de sua integração à ideia subjacente aos standards constitucionais .

\section{Por uma teoria da proporcionalidade legislativa penal: critérios densificadores} para o conceito material de crimes e proporcionalidade das penas ..................... 207

4.1. Proporcionalidade e legislação penal: uma utopia? ................................................... 207

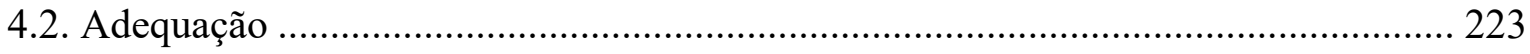

4.2.1. Proteção de bens jurídicos individuais sob escrutínio de mera racionalidade ... 224

4.2.2. Proteção de bens jurídicos coletivos sob escrutínio estrito ............................... 228

4.2.2.1. Critério democrático-constitucionalista .............................................. 231

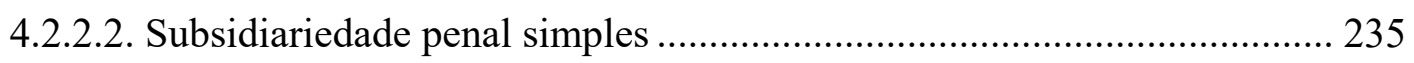

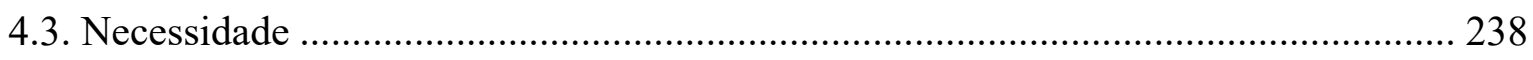

4.3.1. Tipos de dano e de perigo concreto sob escrutínio de mera racionalidade............. 242

4.3.2. Tipos de perigo abstrato sob escrutínio estrito................................................... 244

4.3.2.1. Possibilidades não-fabricadas de dano.................................................... 248

4.3.2.2. Subsidiariedade penal qualificada....................................................... 251

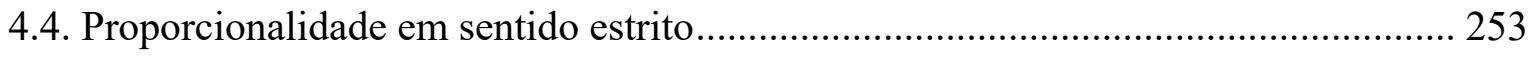

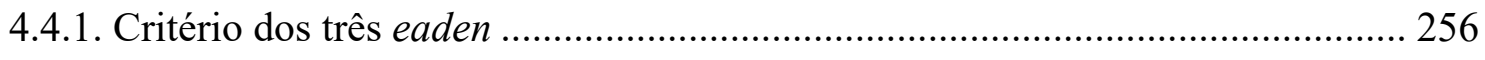

4.4.1.1. Dimensão vertical sob escrutínio de mera racionalidade........................ 257

4.4.1.2. Dimensão horizontal sob escrutínio estrito............................................ 261

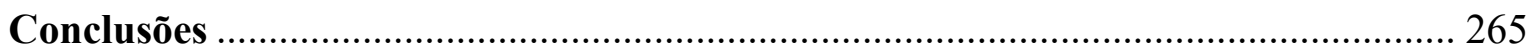

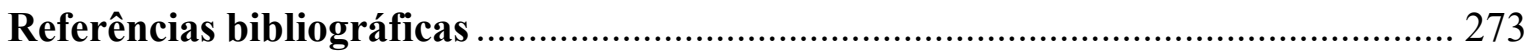




\section{Introdução}

Assim como o ser humano é imperfeito e o mundo não é ideal, leis ilegítimas sempre acompanharam a história da humanidade. Sistemas jurídicos infalíveis são utópicos e apenas habitam o imaginário humano, o que não significa a defesa de sua aceitação resignada, mas, antes, avulta a necessidade de serem acusadas as diversas discrepâncias legislativas, acompanhadas das respectivas propostas de correção.

Atualmente, as injustiças observadas sob o plano legislativo são agudizadas pelos efeitos da pós-modernidade e seus impactos, provavelmente, são mais sensivelmente verificados na edição de leis penais incriminadoras. A busca desenfreada pela eficácia social das medidas punitivas desencadeia um constante desapego pela dogmática penal; a globalização esvazia a soberania estatal e internacionaliza o Direito Penal, principalmente em temas afetos à proteção de direitos humanos, insegurança social e interesses econômicos globalizados; e o aparecimento de riscos mundiais, decorrentes do avanço científíco, tecnológico e das novas perspectivas econômicas, desemboca na antecipação da tutela penal, por meio da punição de comportamentos possivelmente arriscados.

A legislação penal brasileira não é indiferente a essa realidade. As suas disfuncionalidades, sempre verificadas, foram aprofundadas a partir do contato com questões que guardam sintonia direta com o multifacetado conceito da pós-modernidade. Com frequência, o resultado é, por um lado, um crescimento desordenado das normas penais incriminadoras e, por outro, um aumento assimétrico das sanções penais abstratas, consoante a cadência ditada pela normatividade de emergência.

No grande contexto das disfuncionalidades legislativas penais, em alguns casos o problema está no objeto de tutela penal, como ocorre na sua utilização para a proteção de meras imoralidades, como a defesa da organização tradicional da família pelo vestusto artigo 240 do Código Penal, que criminalizava o crime de adultério, e o caso da proteção de interesses abstratos que signficam a defesa de meras funções estatais, a exemplo do art. 22 da Lei Federal 7.492/1986, que se coloca à proteção da função de controle sobre a entrada e saída de dinheiro do país, não se identificando qualquer referência mediata ou indireta com a proteção de interesses individuais.

Para outras hipóteses, ainda que se vislumbre a adequação de se destinar proteção criminal a certo interesse, a questão está na estrutura utilizada para essa proteção, que pode 
representar desnecessário sacrifício à liberdade individual. Por exemplo, muito embora possa se reconhecer a viabilidade da tutela penal do meio ambiente, pode-se enxergar a ilegitimidade de diversas estruturas típicas da Lei Federal 9.605/1998, como o seu art. 51, que criminaliza o comércio ou a utilização de motosserra em quaisquer formas de vegetação, sem licença ou registro da autoridade competente. E, sob outro prisma, pode-se reputar plausível a proteção penal da segurança pública, mas, ainda assim, entender desnecessária a criminalização da posse, dentro da resiência, de uma única munição de uso permitido, como estabelece o art. 12 da Lei Federal 10.826/2003.

Em outros casos, as disfuncionalidades não repousam sobre o objeto ou a forma de proteção penal. Elas recaem sobre as faixas sancionatórias estabelecidas abstratamente pelos preceitos penais secundários, observando-se a desproporcionalidade mediante a comparação entre dois ou mais patamares sancionatórios. Cogita-se, assim, do desequilíbrio entre as penas previstas para o tráfico de drogas (art. 33 da Lei Federal 11.343/2006: 5 a 10 anos de reclusão, e pagamento de 500 a 1.500 dias-multa) e aquelas do art. 273 do Código Penal, que estabelece penas de 10 a 15 anos de reclusão para quem, por exemplo, vende ou tem em depósito para vender produto falsificado, corrompido, adulterado ou alterado. Também pode se acusar a desproporcionalidade entre as penas contempladas para o comércio de CDs ou DVDs “piratas", 2 a 4 anos de reclusão e multa (art. 184, § 2 , Código Penal), e aquelas contempladas para o comércio de programas de computador ("softwares"), que variarão entre 1 e 4 anos de reclusão e multa (art. 12, § 1º, Lei Federal 9.609/1998).

Os dois capítulos iniciais do trabalho serão dedicados a essas questões. No primeiro deles, serão abordadas as questões que se colocam como pano de fundo das desproporcionalidades contemporâneas das leis penais. Elas serão divididas em três bases: a base epistemológica, que cuidará da crise das ciências jurídicas, a partir do embaciamento das próprias ciências sociais, e de como esse quadro desagua no desapego pela dogmática penal e na consequente exaltação da pura eficiência punitiva; a base político-econômica, que se fundamenta no enfraquecimento da soberania estatal pela globalização, o que redunda na internacionalização do Direito Penal, sensivelmente verificada na proteção de direitos humanos de grupos vulneráveis, na difusão de discursos mundiais de insegurança nacional e na defesa de certos interesses econômicos; e a base sociológica, com todas suas repercussões acerca do gerenciamento do risco por meio da intervenção penal. 
A amplitude deste capítulo inicial e a ausência de conclusões preliminares são justificadas a partir da vocação de generalidade do próprio fenômeno da pós-modernidade, cuja análise não pode se restringir a qualquer área do conhecimento, ainda que esta seja a grande área das ciências jurídicas, sem que se considerem suas implicações políticas e sociais.

O segundo capítulo tratará de analisar as principais desproporcionalidades das leis penais brasileiras. Apesar da importância conferida aos reflexos da pós-modernidade, o exame não recairá exclusivamente sobre as disfuncionalidades penais causadas por esse fenômeno da contemporaneidade, também se examinando desequilíbrios entre diversos comandos normativos penais que com ele não apresentam relação evidente e direta. Além disso, a pesquisa recairá sobre as leis penais do Brasil, ainda que implique alusões a diplomas estrangeiros, de maneira que a teoria que será apresentada no último capítulo terá como referência o ordenamento jurídico pátrio, sendo necessária a sua adaptação caso se pretenda aplicá-la para o escrutínio de diplomas estrangeiros. Assim, considerados os corolários do princípio da proporcionalidade, serão examinadas as tutelas penais inadequadas, referindose ao objeto de proteção; as tutelas penais desnecessárias, em atenção à estrutura de proteção; e as tutelas penais estritamente desproporcionais, no que concerne ao quantum de proteção.

Constatadas as diversas desproporcionalidades penais brasileiras, o terceiro capítulo esboçará quais os parâmetros necessários para a criação de instrumentos corretivos desses desequilíbrios. Para tanto, as investigações recairão sobre aspectos da dogmática constitucional sobre a proporcionalidade e os seus subprincípios e, em seguida, ao princípio da razoabilidade e, em especial, como ele se apresenta a partir da construção da jurisprudência dos Estados Unidos da noção dos standards materiais.

Essa aproximação é necessária porque, ao se sugerir a proporcionalidade como critério limitador da intervenção penal, pretende-se aproveitar de sua estrutura, mas preenchê-la a partir dos paradigmas inerentes aos standards materiais, técnicas utilizadas pelo Direito dos Estados Unidos para a aferição da legitimidade das mais diversas restrições estatais a direitos. Esses mecanismos podem se revelar úteis à releitura do princípio da proporcionalidade como instrumento de contenção da intervenção penal, porque, ao mesmo tempo que permitem o agrupamento dos mais importantes critérios limitadores da dogmática penal no recôndito de cada um de seus subprincípio, autorizam-lhes certa flexibilidade, mediante uma maleabilidade que lhes é conceitualmente inerente, desde que, neste último caso, sejam acompanhados por critérios limitadores adicionais. 
O quarto e último capítulo cuidará de apresentar esses critérios densificadores. A proposta é que a teoria da proteção de bens jurídicos seja acomodada pelo subprincípio da adequação, a ofensividade integre o subprincípio da necessidade e a igualdade interaja com o subprincípio da proporcionalidade em sentido estrito.

No bojo dos processos legislativos tendentes à edição de normas penais incriminadoras, caso as propostas legislativas penais prevejam a proteção de interesses individuais ou contemplem a edição de tipos de dano ou de perigo concreto, não haverá a necessidade de serem satisfeitos quaisquer critérios adicionais, de maneia que escrutínios de mera racionalidade devem ser o bastante para a aprovação dessas leis. No entanto, caso as propostas legislativas apartem-se dessas concepções clássicas e proponham a proteção de interesses coletivos ou a edição de tipos de perigo abstrato, sugere-se a existência de critérios limitadores adicionais, que devem ser cumpridos já durante o processo legislativo. Esses critérios, caracterizadores dos escrutínios estritos, no que toca à pretensão de proteção de interesses coletivos, implicarão obediência ao critério democrático-constitucionalista e à subsidiariedade penal simples. Já relativamente à pretensão de edição de tipos de perigo abstrato, tais deveres corresponderão à identificação de possibilidades não-fabricadas de danos e à subsidiariedade penal qualificada.

Por fim, no âmago da proporcionalidade em sentido estrito, em se tratando da análise do equilíbrio sistêmico das faixas penais abstratamente estabelecidas pelos tipos, sua análise considerará três eaden: natureza do bem jurídico, desvalor abstrato da conduta e desvalor abstrato do resultado jurídico. Considerando que carece à proporcionalidade em sentido estrito um princípio de justiça, tal qual a proteção de bens jurídicos para a adequação e a ofensividade para a necessidade, deve haver o cumprimento de critérios adicionais tanto para o escrutínio de mera racionalidade (dimensão vertical), quanto para o escrutínio estrito (dimensão horizontal).

Em todos os casos de cumprimento de deveres adicionais, propõe-se que os legisladores devam se socorrer de duas espécies de comitês e ampliar canais de participação popular. A primeira espécie de comitê deverá ser composta por especialistas das ciências penais e afins e emitir pareceres sobre dois dos três pontos relacionados ao critério democrático-constitucionalista (a fundamentalidade constitucional do interesse coletivo e a medida em que esse interesse coletivo se coloca à proteção de direitos fundamentais individuais. sobre o cumprimento das exigências relacionadas à subsidiariedade penal 
simples e à subsidiariedade penal qualificada e sobre os três eaden referentes aos escrutínios de proporcionalidade em sentido estrito. A outra espécie de comitê, representada por cientistas de diversas áreas do conhecimento, exarará pareceres sobre variadas questões técnicas que eventualmente forem pertinentes para alguns tipos de perigo abstrato. Por fim, a ampliação dos canais de participação popular será útil para a aferição do grau de consenso social sobre o objeto a ser penalmente protegido, sendo esta uma das questões a serem travadas no contexto do critério democrático-constitucionalista.

Eis a contribuição singela que esta pesquisa pretende oferecer. A tônica é a utilização da proporcionalidade como instrumento útil à correção das proporcionalidades legislativas penais, a partir de sua colmatação por critérios relacionados aos standards materiais do Direito dos Estados Unidos. Por um lado, não haverá preocupações relativas a questões exclusivamente procedimentais. Por exemplo, não se cogitará sobre a maneira como se dará a abertura do processo legislativo à participação dos comitês; se deverá ser uma iniciativa das comissões de constituição e justiça, ao se constatar que a proposta visa a proteger penalmente um interesse coletivo por meio de um tipo de perigo abstrato. Tais questões fugiriam ao ponto central destas investigações, voltadas à dogmática penal.

Além disso, pode-se questionar a reduzida factibilidade de o legislador respeitar os pareceres dos comitês, porque ele é movido por interesses de diversas matizes, especialmente de ordem econômica e aqueles exercidos por grupos de pressão. Todavia, ainda que a teoria seja pensada para o processo legislativo, visando ao estabelecimento de procedimentos corretivos preventivos, nada impede que as pesquisas sejam úteis posteriormente, no exercício de eventuais controles de constitucionalidade das leis penais já em vigor, para o enriquecimento do contraditório e à ampliação da cognição judicial sobre o tema.

Com isso, estão enunciados a proposta e o modo em que se organiza este trabalho. Os desequilíbrios das leis penais é assunto abrangente e de alta complexidade e, bem por isso, suscita inquietações a respeito das tentativas de compreensão de seus desdobramentos contemporâneos. Apenas o aproveitamento da máxima possibilidade de rendimento de instituto com semelhante vocação à abrangência e à complexidade, como é o princípio da proporcionalidade, poderá fazer frente a esse fenômeno e se posicionar como instrumento útil à correção dos rumos da intervenção penal. 


\section{Conclusões}

1. No contexto da pós-modernidade, as leis penais brasileiras sofrem grandes transformações. Essas alterações encontram-se basicamente vinculadas à busca por mais eficiência punitiva, maximizada pela proteção de novos interesses e pelo gerenciamento de riscos sociais decorrentes do avanço tecnológico, acarretando certa deturpação dos institutos penais clássicos, além de incrementar a desproporcionalidade das leis penais.

2. Os efeitos da pós-modernidade devem ser adequados sob três vertentes: a base epistemológica, verificando-se a crise das ciências, em geral, e do Direito, em particular, a partir da absolutização da eficácia social das normas; a base político-econômica, com a relativização da soberania estatal pela globalização e a consequente atribuição de caráter transnacional às regras jurídicas; e a base sociológica, com a análise dos contornos da sociedade do risco.

3. Muito embora a eficiência seja uma característica positiva das leis, sua busca não pode implicar o vilipêndio a direitos e garantias fundamentais. No plano das leis penais, o mero eficientismo penal provoca uma invasão desmensurada da intervenção penal em esferas dantes ocupadas exclusivamente pela tutela administrativa, ocasiona incrementos injustificáveis das sanções penais e transforma a política criminal em verdadeira política de segurança pública, acabando por materializar a hegemonia de grupos de pressão sobre o poder público.

4. A globalização flexibiliza a soberania estatal, potencializando a interdependência dos Estados e a transnormatividade, principalmente em questões afetas à proteção de direitos humanos e à preservação de interesses econômicos de grupos hegemônicos. $\mathrm{O}$ primeiro reflexo é o crescimento da tutela penal de direitos humanos, especialmente de grupos de pessoas vulneráveis, o que representa, em princípio, inegável vocação ética por colocar o Estado a serviço da pessoa, e não o contrário. No entanto, é imprescindível que essa proteção especial não vulnere garantias materiais e processuais básicas, igualmente prestigiadas no âmbito internacional. O segundo efeito é a canalização para o interior do ordenamento jurídico-penal nacional de ideias difundidas por discursos hegemônicos de insegurança social, que ocupam a pauta de diversos meios de comunicação, ensejando um clamor pelo recrudescimento das leis penais, medida barata, de propaganda fácil e simbolicamente eficaz. O terceiro e último efeito da globalização é a economização do 
Direito Penal, por meio da utilização da tutela penal como reforço da proteção de interesses econômicos das grandes potências mundiais, com destaque aos Estados Unidos, instrumentalizados por meio de soft laws como acordos, convenções ou recomendações de organismos internacionais como a OCDE, OMC, Banco Mundial e a Câmara de Comércio Internacional.

5. Os riscos atuais são marcados pela globalidade de seu alcance e pela modernidade de suas causas, adquirindo importância as funções públicas e privadas que cuidam de seu gerenciamento. O manejo do risco é opção política, mas esta normalmente não considera estudos científicos e resultados probabilísticos. A Política tende a descarregar sobre o Direito a responsabilidade desse gerenciamento, que é realizado, com frequência, de modo disfuncional. Esse quadro acarreta a administrativização da tutela penal, que passa a ter a pretensão da gestão punitiva de riscos gerais a bens de caráter difuso, por meio da multiplicação de tipos penais de perigo abstrato.

6. As desproporcionalidades da legislação penal são caracterizadas por sua hipertrofia, uma expansão disfuncional do Direito Penal marcada por um crescimento desordenado de normas incriminadoras, por um lado, e pelo aumento assimétrico da quantidade de penas, por outro. Essas disfuncionalidades são normalmente vinculadas a uma normatividade de emergência, que se contrapõe a qualquer política criminal eficiente e racional, ensejando imperfeições técnicas e ineficácia das normas, ambos efeitos de um simbolismo penal estéril.

7. O princípio da proporcionalidade e seus corolários da adequação, necessidade e proporcionalidade em sentido estrito são instrumentos indispensáveis para a busca por equilíbrio e coerência entre as normas jurídicas. Por isso, é viável cogitar-se da existência de tutelas penais inadequadas, quando o interesse que se quer proteger não é digno da tutela penal; tutelas penais desnecessárias, quando o problema não está no interesse a ser protegido penalmente, mas na forma em que essa proteção se dá; e tutelas penais estritamente desproporcionais, hipóteses nas quais a atenção não se volta ao objeto de proteção ou à estrutura do tipo, porém antes à ausência de equilíbrio entre as penas abstratamente cominadas ao preceito penal.

8. São inadequadas as tutelas penais que visam a proibir condutas meramente imorais. É esperado que as normas apresentem carga valorativa, mas se espera que elas se voltem à proteção de interesses ético-jurídicos, delimitados e suficientemente relevantes para se garantir uma coexistência livre e pacífica entre os seres humanos. Normas penais não podem, 
no entanto, voltar-se à proteção exclusiva de valores morais, ainda que compartilhados pela maioria da sociedade, como algumas questões ligadas à sexualidade, à pornografia, tabus, e a meros sentimentos.

9. São inadequadas as tutelas penais de interesses abstratos quando inexistente sua funcionalização ao atendimento dos interesses do indivíduo. Esse exame deverá ser realizado a partir da própria configuração social, porque esta definirá quais realidades sociais podem ser compreendidas como bens jurídicos coletivos dignos de proteção penal.

10. Os tipos penais de perigo abstrato serão desnecessários quando não contemplarem possibilidades não-fabricadas de danos. É o que ocorrerá, por exemplo, quando crimes de ação concretamente perigosa ignorarem dados da realidade empírica e dados técnicos pertinentes, e passarem a proibir condutas absolutamente inofensivas aos bens jurídicopenais.

11. Na seara dos delitos preparatórios, sejam eles de posse ou de status, devem ser estabelecidos parâmetros que indiquem a necessidade da intervenção jurídico-penal, impedindo-se que o legislador conte com a mais ampla liberdade para impor criminalizações desarrazoadas e calcadas em perigos artificiais. Por isso, tais normas devem comunicar comportamentos suficientemente desvalorados, que permitam verificar possibilidades nãofabricadas de dano, mediante o auxílio de dados da realidade empírica e de dados técnicos.

12. Os delitos de acumulação e os delitos de posse e de status que se fundamentem a partir da lógica pós-consumativa sempre serão exemplo de tutela penal inadequada, por infração intransponível ao princípio da ofensividade, porque, sequer remotamente, podem se vislumbrar qualquer possibilidade não-fabricada de dano a bens jurídico-penais.

13. As desproporcionalidades entre as diversas sanções penais estabelecidas abstratamente pelo legislador são aprofundadas pelo discurso pós-moderno, que destaca as funções preventivas negativas da pena, concepções úteis ao atendimento de uma pretensa eficácia punitiva, aos reclames da sociedade do risco e ao modelo penal da segurança cidadã. O medo do perigo e a prevenção são ideias que se fortalecem mutuamente, de modo que o agravamento indiscriminado das sanções, inevitavelmente, traz em si a marca da prevenção.

14. A prevenção geral positiva apenas provocará efeitos preventivos reais quando contemplar um conteúdo mínimo de justiça às normas a serem estabilizadas, por meio da atenção à proporcionalidade das penas. Ainda que inexistam fórmulas matemáticas que 
apontem com exatidão quais seriam os justos montantes das penas, aptos ao estabelecimento de simetria e harmonização entre todas as demais cominações, alguns critérios podem ser observados para que se alcance o mínimo de equilíbrio entre as mais diversas normas penais secundárias. Esses critérios devem ser obtidos das próprias estruturas típicas, a partir da análise de três elementos: a natureza dos bens jurídico-penais, os desvalores abstratos das condutas e os desvalores abstratos dos resultados.

15. Deve haver um necessário imbricamento entre a dogmática constitucional e a dogmática penal, de modo que seus institutos, ao mesmo tempo que limitam e conferem razoabilidade à intervenção punitiva, ressoem o espírito constitucional democrático. $\mathrm{O}$ melhor instrumento para esse fim é o princípio da proporcionalidade e seus corolários da adequação, necessidade e proporcionalidade em sentido estrito, indispensáveis para a manutenção da harmonia não apenas próprio texto constitucional, mas para 0 estabelecimento de coerência dos demais ramos jurídicos, que encontram assento imediato ou remoto nas próprias normas constitucionais.

16. No âmbito penal, o princípio da proporcionalidade vai além do mero exercício de correspondência entre gravidade do fato e gravidade da pena, podendo oferecer sólidos fundamentos para o exame da legitimidade da intervenção punitiva. Por causa de sua vocação integradora, a proporcionalidade permite que diversos institutos penais possam assumir roupagem constitucional. Uma grande dificuldade é o seu caráter dúctil que, apesar de se harmonizar à ausência de rigidez de conceitos da pós-modernidade, permite a projeção de diversas incertezas.

17. A razoabilidade não é sinônimo da proporcionalidade, apesar de ambas visarem aos mesmos fins. A construção da primeira é devida aos sistemas de common law, especialmente ao Direito dos Estados Unidos. Apesar de sua menor sofisticação teórica, a razoabilidade poderá contribuir satisfatoriamente à aferição da legitimidade das leis a partir do estudo teoria dos escrutínios ou standards constitucionais (escrutínio estrito, escrutínio intermediário e escrutínio de mera racionalidade) que lhe é inerente, e não guarda correspondência com qualquer elemento teórico relacionado à proporcionalidade.

18. É necessário o estabelecimento das bases de uma Ciência da Legislação Penal que, com a necessária deferência ao princípio democrático, avalie as opções político-criminais do legislador. As leis penais não podem ser infensas a qualquer controle científico, devendo 
se fundar em razões legítimas, devidamente explicitadas nos processos legislativos tendentes à edição de tipos penais incriminadores.

19. A análise da proporcionalidade das leis penais deverá tomar por base a estrutura do princípio da proporcionalidade e de seus elementos, porém o interior destes deverá ser preenchido por critérios que se movem a partir da lógica subjacente aos escrutínios constitucionais que, em síntese, modulam as exigências para a aferição da legitimidade das leis, a partir da natureza dos direitos por ela restringidos. Justamente porque ela não obedece à lógica do tudo ou nada, por meio da proporcionalidade, combinada com as ideias que fundamentam a teoria dos standards constitucionais, ao mesmo tempo em que são preservados clássicos institutos e critérios limitadores da intervenção penal, admite-se sua flexibilização, a depender de certos requisitos e desde que sejam obedecidos certos limites formais e materiais.

20. Em termos estritamente penais, o subprincípio da adequação diz respeito àquilo que pode ser objeto de proteção por meio do Direito Penal; em outras palavras, a tudo aquilo que pode ser classificado como bem jurídico-penal. Leis penais que tutelem diretamente interesses individuais devem se submeter ao escrutínio de mera racionalidade, bastando que se vislumbre no interesse individual protegido uma conexão com um direito fundamental da pessoa humana, ainda que este não esteja expressamente previsto no texto constitucional.

21. Os interesses individuais compõem o núcleo do significado de bem jurídico-penal. Já as questões exclusivamente morais, como alguns aspectos da sexualidade, da pornografia e mesmo da proteção de meros sentimentos, como o sentimento religioso ou de respeito aos mortos habitam o resto do mundo, de maneira que nunca poderão ser erigidas à categoria de bem jurídico-penal.

22. Os demais interesses coletivos circundam a periferia do significado desse instituto jurídico. Por esse motivo, atentem à lógica cambiante e devem se submeter a alguns critérios delimitadores adicionais. Em relação a eles, o legislador deve cumprir deveres especiais de duas ordens: atenção ao critério democrático-constitucionalista e à subsidiariedade penal simples. O primeiro feixe de deveres especiais implica na identificação, pelo legislador, da fundamentalidade constitucional do interesse coletivo; da medida em que esse interesse coletivo se coloca à proteção de direitos fundamentais individuais; e do grau de consenso social sobre a matéria. O segundo feixe de deveres especiais redunda na constatação de que a intervenção penal, por ser a medida estatal mais gravosa na liberdade do indivíduo, 
somente poderá ser utilizado quando o Estado não dispuser de outros meios menos severos para impedir a prática de comportamentos que se quer coibir.

23. Deverão ser formados comitês compostos por especialistas em ciências criminais e áreas correlatas, que emitirão pareceres em torno da referência constitucional ao interesse coletivo, sua funcionalidade à satisfação de interesses individuais fundamentais, bem como da insuficiência de formas extrapenais de proteção. Por seu turno, a aferição do grau de consenso social sobre a matéria advirá da ampliação dos canais de participação popular, a partir do aperfeiçoamento das audiências públicas, utilização frequente de plebiscitos e referendos, a implementação de conselhos populares heterodoxos e pesquisas e opinião.

24. Para o Direito Penal, o subprincípio da necessidade relaciona-se ao exame das estruturas típicas utilizadas. Tipos penais de dano e de perigo concreto devem se submeter ao escrutínio de mera racionalidade, à medida que essas estruturas se conformam à própria essência do princípio da ofensividade, centrada na ideia de produção de um resultado palpável e, por isso mesmo, eles representam o núcleo do significado de ofensividade.

25. Por sua vez, os delitos de acumulação, os crimes de posse que atendem à lógica pósconsumativa e os crimes de status que não atendem à lógica pré-consumativa compõem o chamado resto do mundo do conceito de ofensividade, porque elas não representam, sequer sob a perspectiva abstrata, qualquer possibilidade, ainda que remota, de perigo ao bem jurídico tutelado pela norma penal.

26. As demais modalidades de tipos de perigo abstrato - crimes de ação concretamente perigosa e demais infrações de posse e de status, desde que fundadas na lógica préconsumativa - situam-se na periferia do significado de ofensividade porque, apesar de carecerem de substrato empírico, são passíveis de contemplar condutas que possam realmente representar algum grau de perigo ao interesse protegido pela norma. A sua legitimidade estará condicionada à satisfação de deveres especiais de duas categorias: as possibilidades não-fabricadas de danos e a subsidiariedade penal qualificada.

27. As possibilidades não-fabricadas de danos dizem respeito ao acesso a dados científicos e dados empíricos, congregados, quando necessário, a uma finalidade especial de agir. O alcance aos dados técnicos ocorrerá por meio da abertura do procedimento legislativo a diálogos com cientistas das matérias que interessem a certos projetos de lei, compondo-se comitês de especialistas, nos quais se observe a maior diversidade possível das correntes de 
estudos sobre dada matéria. Por sua vez, os dados empíricos serão obtidos a partir do acesso à realidade dos fatos, trazendo-se para o bojo dos projetos de leis as informações fáticas pertinentes. De modo específico, em se tratando dos delitos preparatórios de posse e de status, as possibilidades não-fabricadas de dano, ao lado dos dados técnicos e dos dados empíricos, dependerá da inserção típica de uma finalidade especial de agir, ou seja, uma finalidade especifica de realizar ou de contribuir com um comportamento delitivo final, que dê sentido à própria proibição antecipada dessas condutas.

28. Já a subsidiariedade penal qualificada representa a existência de discussões técnicas acerca da efetiva necessidade de utilização da estrutura dos tipos de perigo abstrato. Para o seu cumprimento, aqueles mesmos comitês compostos por especialistas das ciências criminais e afins deverão apresentar estudos acerca da possibilidade de os interesses penalmente relevantes serem protegidos por meio das estruturas de tipos de dano ou de perigo concreto e, apenas na eventualidade da inidoneidade dessas formas de proteção, a partir de tipos de perigo abstrato.

29. A leitura penal do subprincípio da proporcionalidade em sentido estrito redunda na aferição sobre o equilíbrio sistêmico das penas mínimas e máximas que se pretende estabelecer em dados preceitos penais secundários. Para a realização desse exame, o princípio da igualdade deve ser densificado a partir de três critérios particulares (“eaden"), identificados no âmbito de cada tipo penal, nomeadamente: natureza dos bens jurídicos, desvalores abstratos das condutas e desvalores abstratos dos resultados.

30. Quando não houver coincidência exata entre os três eaden, o escrutínio aplicado será o de mera racionalidade. Nesses casos, vislumbra-se uma dimensão vertical, a partir da hierarquização desses níveis. Quanto aos interesses individuais, quanto mais próximos ao núcleo da dignidade humana, mais importantes serão e, no que tange aos interesses coletivos, sua importância crescerá quanto mais próxima for sua funcionalização à proteção de direitos fundamentais individuais. No que toca aos desvalores abstratos das condutas, relativamente à tipicidade subjetiva, conclui-se que condutas dolosas são mais graves que condutas culposas e, quanto à tipicidade objetiva, algumas vicissitudes podem representar um plus ou um minus de severidade, além de crimes permanentes autorizarem, em princípio, penas mais elevadas do que crimes instantâneos. Finalmente, no que concerne aos desvalores dos resultados, as formas consumadas devem receber reproches superiores às correspondentes modalidades tentadas e estas, por sua vez, por estarem mais próximas à consumação, devem 
contemplar penas superiores a eventuais previsões típicas de punições de atos preparatórios. Ainda, as penas dos crimes de dano devem ser, como regra, superiores às penas dos crimes de perigo concreto e estas mais elevadas do que as correspondentes aos tipos de perigo abstrato. E, por fim, assim como se observa com os desvalores abstratos das condutas, condições especializantes podem representar um agravamento especial relativamente aos resultados.

31. A proporcionalidade em sentido estrito carece de um princípio de justiça como fundamento. Essa deficiência deverá ser suprida pelo cumprimento de deveres especiais pelo legislador, mesmo em se tratando do escrutínio de mera racionalidade.

32. Em se tratando do escrutínio de mera racionalidade, esses deveres especiais consistirão na participação de comitês de especialistas em ciências penais e áreas afins, cujas tarefas também contemplarão a emissão de pareceres acerca da proporcionalidade das penas mínimas e máximas dos futuros tipos penais, a partir de sua contextualização com os mais diversos preceitos penais secundários já existentes no ordenamento jurídico brasileiro. Nesses casos, considerada a dimensão vertical, desde que sejam observados os limites mínimos tracejados pelos três eaden, confere-se deferência às quantidades de penais eleitas pelo legislador, que naturalmente gozará de maior âmbito de liberdade para o estabelecimento dos patamares sancionatórios abstratos.

33. Entretanto, nas situações em que existir coincidência exata entre os três eaden, o escrutínio será estrito, vislumbrando-se uma dimensão horizontal. Como regra, inexistindo diferenças entre os três elementos, as penas estabelecidas para dois os mais tipos devem ser idênticas. No entanto, na eventualidade de as penas serem diversas, somente se poderá concluir pela legitimidade desse discrímen se ele se embasar em razões sociais constrangedoras, devidamente indicadas pelos estudos e pareceres exarados pelo comitê de especialistas em ciências penais e áreas afins. 


\section{Referências bibliográficas}

ACCIOLI, Wilson. Teoria geral do estado. Rio de Janeiro: Forense, 1985.

ADAMS, Bruce; SHERMAN, Betsy. Sunset implementation: a positive partnership to make government work. Public Administration Review, v. 38, n. 1, pp. 78-81, 1978.

AGAMBEN, Giorgio. Homo sacer: o poder soberano e a vida nua. $2^{\mathrm{a}}$ ed. Trad. Henrique Burigo. Belo Horizonte: UFMG, 2010.

AGUADO CORREA, Teresa. El principio de proporcionalidad en derecho penal. Madrid: Edersa, 1999.

ALCÁCER GUIRAO, Rafael. El derecho a la legalidad penal y los límites de actuación del Tribunal Constitucional. In: MIR PUIG, Santiago; QUERALT JIMÉNEZ, Joan; FERNANDEZ BAUTISTA, Silvia (coord.). Constitución y princípios del derecho penal: algunas bases constitucionales. Valencia: Tirant lo Blanch, pp. 15-66, 2010.

ALEXY, Robert. Constitucionalismo discursivo. Trad. Luís Afonso Heck. Porto Alegre: Livraria do Advogado, 2011.

Malheiros, 2008.

. Teoria dos direitos fundamentais. Trad. Virgílio Afonso da Silva. São Paulo:

ALPÍZAR CHAVES, Alberto. Función de taxatividad del tipo penal: mandato de certeza "lex certa". Revista de la Asociación de Ciencias Penales de Costa Rica, n. 24, v. 17, pp. 34-43, 2007.

ALVES, José Augusto Lindgreen. Os direitos humanos na pós-modernidade. São Paulo: Perspectiva, 2005.

AMARAL, Claudio do Prado. Bases teóricas da ciência penal contemporânea: dogmática, missão do direito penal e política criminal na sociedade do risco. São Paulo: IBCCRIM, 2007.

AMARO, Luciano. Direito tributário brasileiro. $9^{\text {a }}$ ed. São Paulo: Saraiva, 2003.

AMELUNG, Knut. El concepto “bien jurídico” en la teoría de la protección penal de bienes jurídicos. Trad. Íñigo Ortiz de Urbina Gimeno. In: HEFENDEHL, Roland; HIRSCH, Andrew von e WOHLERS, Wolfgang (eds.). La teoría del bien jurídico. ¿Fundamento de legitimación del derecho penal o juego de abalorios dogmático? Madrid: Marcial Pons, pp. 221-257, 2016. 
AMBOS, Kai. Sobre o futuro da ciência jurídico-penal alemã: abertura e método discursivo no lugar de provincianismo presunçoso. Trad. Chiavelli Facenda Falavigno. Revista Brasileira de Ciências Criminais, São Paulo, n. 121, pp. 127-160, 2016.

ANDRADE, Manoel da Costa. Consentimento e acordo em direito penal: contributo para a fundamentação de um paradigma dualista. Coimbra: Coimbra Editora, 2004.

ANGIONI, Francesco. Contenuto e funzioni del concetto di bene giurídico. Milão: Giuffrè, 1983.

APONTE CARDONA, Alejandro. El derecho penal em una perspectiva de paz: de la tensión entre eficientismo y garantismo em el caso colombiano. Sistemas judiciales, n. 1, v. 1, pp. 156-161, 2001.

ARAGÃO, Alexandre Santos de. As agências reguladoras independentes e a separação de poderes: uma contribuição da teoria dos ordenamentos setoriais. Revista Eletrônica de Direito Administrativo Econômico, n. 10, 2007, p. 14. Disponível em file://C:/Users/tfilippo/Downloads/ARAG\%C3\%83O\%252c\%20Alexandre\%20Santos\%2 0de\%252c\%20Ag\%C3\%AAncias\%20Reguladoras\%20e\%20Triparti\%C3\%A7\%C3\%A3o $\% 20$ dos\%20Poderes\%20(1).pdf. Acesso em 24.01.2018.

ÁVILA, Humberto. Teoria dos princípios: da definição à aplicação dos princípios jurídicos. $18^{\mathrm{a}}$ ed. São Paulo: Malheiros, 2018.

AZEVEDO, David Teixeira. O crime de receptação e formas de execução dolosa: direta e eventual. In: AZEVEDO, David Teixeira. Atualidades no direito e processo penal. São Paulo: Método, 2001.

BADARÓ, Gustavo Henrique Righi Ivahy. O ônus da prova no processo penal. São Paulo: Revista dos Tribunais, 2003.

BAHGWAT, Ashutosh. Purpose scrutiny in constitutional analysis. California Law Review, v. 85, pp. 299-369, 1997.

BARATTA, Alessandro. Funciones instrumentales y simbólicas del derecho penal. Trad. Mauricio Martínez Sánchez. Revista Hispano-latinoamericana Pena y Estado, Barcelona, n. 1, pp. 37-55, 1991.

. Principi del diritto penale minimo: per una teoria dei diritti umani come oggetti e limiti della legge penale. Dei delitti e delle pene. Rivista de Studi Sociali, Storici e Giuridici Sulla Questione Criminale, Bologna, v. 3, n. 3, pp. 443-573, 1985.

BARJA DE QUIROGA, Jacobo Lopes. El moderno derecho penal para una sociedad de riesgo. Madrid: Poder Judicial, 1997. 
BARROS, Suzana de Toledo. O princípio da proporcionalidade e o controle de constitucionalidade das leis restritivas de direitos fundamentais. Brasília: Brasília Jurídica, 1996.

BARROSO, Luís Roberto. A americanização do direito constitucional e seus paradoxos: teoria e jurisprudência constitucional no mundo contemporâneo. In: SARMENTO, Daniel (coord.). Filosofia e teoria constitucional contemporânea. Rio de Janeiro: Lumen Juris, pp. 309-345, 2009.

- A dignidade da pessoa humana no direito constitucional contemporâneo: a construção de um conceito jurídico à luz da jurisprudência mundial. Belo Horizonte: Fórum, 2013.

. Curso de direito constitucional contemporâneo. $3^{\mathrm{a}}$ ed. São Paulo: Saraiva, 2011.

. Interpretação e aplicação da constituição. 6a ed. São Paulo: Saraiva, 2008.

BATISTA, Nilo. Apontamentos para uma história da legislação penal brasileira. Rio de Janeiro: Revan, 2016.

. Introdução crítica ao direito penal brasileiro. 12a ed. Rio de Janeiro: Revan, 2011.

BAUMAN, Zygmunt. Tempos líquidos. Trad. Carlos Alberto de Medeiros. Rio de Janeiro: Zahar, 2007.

BECCARIA, Cesare. Dos delitos e das penas. Trad. Paulo M. Oliveira. 13 ${ }^{\text {a }}$ ed. São Paulo: Ediouro, 1999.

BECHARA, Ana Elisa Liberatore Silva. Bem jurídico-penal. São Paulo: Quartier Latin, 2014.

. Delitos de acumulação e racionalidade da intervenção penal. Boletim IBCCRIM, São Paulo, n. 208, v. 17, pp. 3-5, 2010.

. Direitos humanos e direito penal: limites da intervenção penal racional no estado democrático de direito. In: MENDES, Gilmar Ferreira; BOTTINI, Pierpaolo Cruz e PACELLI, Eugenio. Direito penal contemporâneo: questões controvertidas. São Paulo: Saraiva, pp. 153-194, 2011.

. Discursos de emergência e política criminal: o futuro do direito penal brasileiro. Revista da Faculdade de Direito da Universidade de São Paulo, v. 103, pp. 411-436, 2008.

. Genética e direito penal. Boletim IBCCRIM, São Paulo, ano 16, n. 238, pp. 8-9, 
. Os discursos de emergência e o comprometimento da consideração sistêmica do direito penal. Boletim IBCCRIM, São Paulo, ano 16, n. 190, p. 17, 2008.

. O rendimento da teoria do bem jurídico no direito penal contemporâneo. Revista Liberdades, São Paulo, v. 01, pp. 16-30, 2009.

. Valor, norma e injusto penal: considerações sobre os elementos normativos do tipo objetivo no direito penal contemporâneo. Vol. 10. Coord. Cláudio Brandão. Belo Horizonte: D'Plácido, 2018.

BECK, Ulrich. A reinvenção da política: rumo a uma teoria da modernização reflexiva. In: GIDDENS, Anthony; BECK, Ulrich e LASH, Scott. Modernização reflexiva: política, tradição e estética na ordem social moderna. Trad. Magda Lopes. São Paulo: UNESP, 1997.

. Sociedade de risco: rumo a uma outra modernidade. Trad. Sebastião Nascimento. São Paulo: Editora 34, 2010.

BENNET, John. The diversity ruse: how Grutter upheld affirmative action by failing to apply strict scrutiny. Cumberland Law Review, v. 45, pp. 225-301, 2015.

BERDUGO GÓMEZ DE LA TORRE, Ignacio e CEPEDA, Ana Pérez. Derechos humanos $y$ derecho penal. Validez de las viejas respuestas frente a las nuevas cuestiones. Revista Penal Mexico, n. 1, pp. 30-64, 2011.

BERNARDI, Alessandro. Sui rapporti tra diritto penale e soft law. Rivista Italiana di Diritto e Procedura Penale, n. 2, v. 54, pp.536-583, 2011.

BIANCHINI, Alice. Pressupostos materiais mínimos da tutela penal. São Paulo: Revista dos Tribunais, 2002.

BIRBAUM, Johann Michael Franz. Sobre la necesidad de una lesión de derechos para el concepto de delito. Trad. José Luis Guzmán Dalbora. Buenos Aires: B de F, 2010.

BISI, Adriana de Oliveira Gonzaga; LEONEL, Wilton Bisi; CARVALHO, Thiago Fabres de. Direito penal do inimigo e lei de segurança nacional de 1935, no Brasil. Revista Brasileira de Ciências Criminais, São Paulo, n. 137, v. 25, pp. 17-62, 2017.

BITENCOURT, Cezar Roberto. Falência da pena de prisão: causas e alternativas. 5a ed. São Paulo: Saraiva, 2017.

. Tratado de direito penal: parte especial. Vol. 3. 4ª ed. São Paulo: Saraiva, 2008.

; MONTEIRO, Luciana de Oliveira. Crimes contra a ordem tributária. São Paulo: Saraiva, 2013. 
; . A desproporcional cominação de penas pelo art. 273 do código penal e sua inconstitucionalidade. In: ZILIO, Jacson Luiz; BOZZA, Fábio da Silva. Estudos críticos sobre o sistema penal. Curitiba, LedZe, pp. 1.031-1.056, 2012

BITTAR, Eduardo Carlos Bianca. O direito na pós-modernidade. Rio de Janeiro: Forense Universitária, 2003.

BLANCO DE MORAIS, Carlos. Manual de legística: critérios cientificos e técnicos para legislar melhor. Lisboa: Verbo, 2007.

BLOND, Neil C. Constitutional law. Nova Iorque: Aspen Publishers, 2009.

BOBBIO, Norberto. A era dos direitos. Trad. Carlos Nelson Coutinho. São Paulo: Campus, 1992.

1996.

. Igualdade e liberdade. Trad. Carlos Nelson Coutinho. Rio de Janeiro: Ediouro, . O positivismo jurídico: lições de filosofia do direito. Trad. Márcio Pugliesi, Edson Bini e Carlos E. Rodrigues. São Paulo: Ícone, 2006.

BONAVIDES, Paulo. Teoria do Estado. 6a ed. São Paulo: Malheiros, 2007.

BOSCHI, José Antônio Paganella. Das penas e seus critérios de aplicação. $7^{\mathrm{a}}$ ed. Porto Alegre: Livraria do Advogado, 2014.

BOTTINI, Pierpaolo Cruz. A confusa exegese do princípio da insignificância. In: RASCOVSKI, Luiz (coord.). Temas Relevantes de Direito Penal. São Paulo: Saraiva, pp. 237-252, 2012.

. Crimes de perigo abstrato. 3a ed. São Paulo: Revista dos Tribunais, 2013.

- O princípio da proporcionalidade na produção legislativa brasileira e seu controle judicial. Revista Brasileira de Ciências Criminais, São Paulo, v. 18, n. 85, pp. 267296, 2010.

BOZZA, Fábio da Silva. Bem jurídico e proibição de excesso como limites à expansão penal. São Paulo: Almedina, 2015.

BRANDÃO, Cláudio e SIQUEIRA, Leonardo. Tipicidade e perigo: para a compreensão da recepção penal da dicotomia do risco e do perigo. Revista de Estudos Criminais, Porto Alegre, n. 61, v. 15, 2016.

BRASIL. Declaração do Rio sobre meio ambiente e desenvolvimento. Disponível em "http://www.onu.org.br/rio20/img/2012/01/rio92.pdf.". Acesso em 26.02.2018. 
BRASIL. Pacote anticrime. Disponível em: https://cdn.oantagonista.net/uploads/2019/02/MJSP-Projeto-de-Lei-Anticrime.pdf. Acesso em 30.04.2019.

BREYER, Stephen. Active liberty: interpreting our democratic Constitution. Nova Iorque: Alfred A. Knopf, 2007.

BRICOLA, Franco. Teoría general del delito. Trad. Diana Restrepo Rodríguez. Buenos Aires: IBdeF, 2012.

BRITTO, Carlos Ayres. O humanismo como categoria constitucional. Belo Horizonte: Fórum, 2010.

BRUNO, Aníbal. Das penas. 4a ed. Rio: Rio de Janeiro, 1976.

BUSATO, Paulo César. Direito penal: parte geral. $3^{\mathrm{a}}$ ed. São Paulo: Atlas, 2017.

CABRAL, Juliana. Os tipos de perigo \& a pós-modernidade. Rio de Janeiro: Revan, 2005.

CACIEDO, Patrick. Pena e funcionalismo sistêmico: uma análise crítica da prevenção geral positiva. Dissertação de Mestrado. Universidade de São Paulo, 2014.

CAETANO, Marcelo. Princípios fundamentais de direito administrativo. Rio de Janeiro: Forense, 1977.

CALATAYUD, Manuel Maroto. Evaluación y racionalidad político-criminal en los procedimientos legislativos: el ejemplo de Suecia. In: MARTÍN, Adán Nieto et al. Hacia una evaluación de las leyes penales. Madrid: Marcial Pons, pp. 179-199, 2016.

CALLEGARI, André Luis e WERMUTH, Maiquel Ângelo Dezordi. La expansión del derecho penal, sociedad del riesgo y crimen organizado. Revista Peruana de Ciencias Penales, Lima, n. 24, pp. 93-120, 2012.

CAMARGO, Antônio Luís Chaves. Sistema de penas, dogmática jurídico-penal e política criminal. São Paulo: Cultural Paulista, 2002.

CAMARGO, José Aparecido. Teoria dos sistemas: autopoiese e alopoiese. Anais do XVIII Congresso Nacional do CONPEDI, pp. 3152-3191, 2009.

CANARIS, Claus-Wilhelm. Pensamento sistemático e conceito de sistema na ciência do direito. Trad. Antônio Manuel da Rocha e Menezes Cordeiro. Lisboa: Serviço de Educação Fundação Calouste Gulbenkian, 1996.

CANCIO MELIÁ, Manuel. "Direito penal” do inimigo? Trad. André Luis Callegari e Nereu José Giacomoli. In: CALLEGARI, André Luis e GIACOMOLI, Nereu José. Direito penal do inimigo: noções e críticas. Porto Alegre: Livraria do Advogado, 2005. 
CANOTILHO, José Joaquim Gomes; MOREIRA, Vital. Constituição da república portuguesa anotada. Vol. I. São Paulo: Revista dos Tribunais, 2007.

CAPANO, Evandro Fabiani. Dignidade sexual. São Paulo: Revista dos Tribunais, 2009.

CARBONELL, Miguel. Neoconstitucionalismo: elementos para una definición. In: MOREIRA, Eduardo Ribeiro e PUGLIESI, Marcio (coords.). 20 anos da Constituição brasileira. São Paulo: Saraiva, pp. 197-208, 2009.

CARBONELl MATEU, Juan Carlos. Derecho penal: concepto y principios constitucionales. 2 ${ }^{\text {a }}$ ed. Valencia: Tirant lo Blanch, 1996.

CARNEIRO, Henrique. Pequena enciclopédia da histórica das drogas e bebidas. Rio de Janeiro: Elsevier, 2005;

CARO CORIA, Dino Carlos. Sociedades de riesgo, bienes jurídicos colectivos y reglas concursales para la determinación de la pena en los delitos de peligro con verificación de resultado lesivo. Revista Peruana de Ciencias Penales, Lima, n. 9, pp. 177-219, 1999.

CARRINO, Agostino. Hans Kelsen e Eugen Ehrlich. Scienza Giuridica e Sociologia del Diritto. Napoli: Edizioni Scientifiche Italiane, p. 5-33, 1992.

CARVALHO, Érika Mendes de. A técnica dos valores-limite e os delitos de perigo abstrato. Boletim IBCCRIM, São Paulo, n. 238, v. 19, pp. 14-15, 2011.

CARVALHO, Érika Mendes de e CARVALHO, Gisele Mendes de. Direito penal do risco e responsabilidade penal das pessoas jurídicas: a propósito da orientação jurisprudencial do Superior Tribunal de Justiça. In: PRADO, Luiz Regis e DOTTI, René Ariel. Responsabilidade penal da pessoa jurídica: em defesa do princípio da imputação penal subjetiva. $3^{\text {a }}$ ed. São Paulo: Revista dos Tribunais, 2010.

CARVALHO, Salo de. A política criminal de drogas no Brasil: estudo criminológico e dogmático da Lei 11.343/06. $8^{\text {a }}$ ed. São Paulo: Saraiva, 2016.

. Em defesa da lei de responsabilidade político-criminal. Boletim IBCCRIM, São Paulo, n. 193, v. 16, pp. 8-10, 2008.

CASABONA, Carlos Maria Romeo. Los delitos de comisión por omisión: delimitación, insuficiencias y perspectiva político-criminal, politica criminal y reforma penal. In: Homenaje a la memoria del Prof. Dr. D. Juan del Rosal. Madrid: Editoriales de Derecho Reunidas, pp. 925-938, 1993.

CASTELLS, Manuel. A sociedade em rede. Trad. Roneide Venâncio Majer. Vol. I. São Paulo: Paz e Terra, 1999. 
CASTIÑEIRA, Maria Teresa; RAGUÉS, Ramón. Three strikes: el principio de proporcionalidad en la jurisprudencia del Tribunal Supremo de los Estados Unidos. Revista de Derecho Penal y Criminologia, Madrid, n. 14, pp. 58-85, 2004.

CATÃO, Yolanda. Notas sobre a punição do adultério e descriminalização. Revista de Direito Penal, Rio de Janeiro, 13/14, pp. 68-75, 1974.

CEREZO MIR, José. Los delitos de peligro abstracto en el ámbito de derecho penal del riesgo. Revista de Derecho Penal y Criminología, Madrid, n. 10, pp. 47-72, 2002.

CERVINI, Raul. Princípios de cooperação judicial penal internacional no protocolo do Mercosul. São Paulo: Revista dos Tribunais, 2000.

CHEMERINSKY, Erwin. Constitucional law: principles and policies. 2a ed. Nova Iorque: Aspen, 2002.

CIRINO DOS SANTOS, Juarez. Direito penal: parte geral. $7^{\mathrm{a}}$ ed. Florianópolis: Empório do Direito, 2017.

COBO DEL ROSAL, Manuel; VIVES ANTÓN, Tomás S. Derecho penal: parte general. $5^{\mathrm{a}}$ ed. Valencia: Tirant lo Blanch, 1999.

COELHO, Luiz Fernando. Saudade do futuro: transmodernidade, direito e utopia. $2^{\mathrm{a}}$ ed. Curitiba: Juruá, 2010.

CORBETTA, Stefano. La cornice editalle della pena e il sindicato de legitimittà costituzionale. Rivista Italiana di Diritto e Procedura Penale, Milão, v. 40, n. 1, pp. 137-174, 1997.

COSTA, Helena Regina Lobo da. A dignidade humana: teorias de prevenção geral positiva. São Paulo: Revista dos Tribunais, 2008. . Proteção penal ambiental. São Paulo: Saraiva, 2010.

COSTA, José de Faria. O princípio da igualdade, o direito penal e a constituição. Revista Brasileira de Ciências Criminais, São Paulo, v. 21, n. 100, pp. 227-252, 2013.

CUNHA, Maria da Conceição Ferreira da. Constituição e crime: uma perspectiva da criminalização e da descriminalização. Porto: Universidade Católica Portuguesa: 1995.

CUNHA, Rogério Sanches; PINTO, Ronaldo Batista. Violência doméstica: lei Maria da Penha comentada artigo por artigo. $3^{\text {a }}$ ed. São Paulo: Revista dos Tribunais, 2011.

DALLARI, Dalmo de Abreu. Elementos de teoria geral do estado. 19a ed. São Paulo: Saraiva, 1995. 
DAVID, Décio Franco. Delitos de acumulação e proteção ambiental. Belo Horizonte: D’Plácido, 2017.

D’ÁVILA, Fábio Roberto. Antecedentes históricos do Código Penal brasileiro. Revista de Estudos Criminais, Porto Alegre, n. 43, v. 10, pp. 117-134, 2011.

. Ofensividade em direito penal: escritos sobre a teoria do crime como ofensa a bens jurídicos. Porto Alegre: Livraria do Advogado, 2009.

. O ilícito penal nos crimes ambientais. Algumas reflexões sobre a ofensa a bens jurídicos e os crimes de perigo abstrato no âmbito do direito penal ambiental. Revista Brasileira de Ciências Criminais, São Paulo, ano 15, n. 67, pp. 29-58, 2007.

DE FILIPPO, Thiago Baldani Gomes. Aborto: Estados Unidos e Brasil, um estudo comparado. São Paulo: IPAM, 2015.

DE GIORGI, Raffaele. Direito, tempo e memória. Trad. Guilherme Leite Gonçalves. São Paulo: Quartier Latin, 2006.

. O risco na sociedade contemporânea. Trad. Cristiano Paixão, Daniela Nicola e Samantha Dobrwolski. Revista Sequência, Florianópolis, n. 28, 1994

DELMAS-MARTY, Mireille. Trois défis pour un droit mondial. Paris: Éditions Du Seuil, 1998.

DEL PINO, Ana María Prieto. Los contenidos de racionalidad del principio de proporcionalidad en sentido amplio: el principio de subsidiariedad. In: MARTÍN, Adán Nieto et al. Hacia una evaluación de las leyes penales. Madrid: Marcial Pons, 2016.

DEL VECCHIO, Giorgio. Teoria do estado. Trad. Antônio Pinto de Carvalho. São Paulo: Saraiva, 1957.

DIAS, Augusto Silva. "What if everybody did it?: sobre a 'incapacidade de ressonância' do direito penal à figura da acumulação. Revista Portuguesa de Ciência Criminal, Coimbra, n. 3, v. 13, pp. 303-345, 2003.

DIAS, Jorge de Figueiredo. Direito penal: parte geral. Vol. I. São Paulo: Revista dos Tribunais, 2007.

$O$ direito penal entre a sociedade industrial e a sociedade do risco. Revista Brasileira de Ciências Criminais, São Paulo, n. 33, pp. 39-65, 2001.

DIAS, Maria Berenice. Lei Maria da Penha: a efetividade da Lei 11.340/2006 de combate à violência doméstica e familiar contra a mulher. $4^{\mathrm{a}}$ ed. São Paulo: Revista dos Tribunais, 2015. 
DÍEZ RIPOLLÉS, José Luís. A racionalidade das leis penais: teoria e prática. $2^{\mathrm{a}}$ ed. Trad. Luiz Regis Prado. São Paulo: Revista dos Tribunais, 2016.

. Da sociedade do risco à segurança cidadã: um debate desfocado. Revista Portuguesa de Ciência Criminal, Coimbra, n. 4, vol. 17, pp. 547-599, 2007.

. O direito penal simbólico e os efeitos da pena. Trad. Luciana Caetano da Silva. Revista da Associação Brasileira de Professores de Ciências Penais, v. 1, n. 1, pp. 24-49, 2004.

DOLCINI, Emilio. Legi penali “ad personam”, riserva di leggi e principio costituzionale di eguaglianza. Rivista italiana di Diritto e Procedura Penale, Milão, v. 47, n. 1, pp. 50-70, 2004.

DONINI, Massimo. Il principio di offensività: dalla penalistica italiana ai programmi europei. Diritto Penale Contemporaneo, Milão, n. 4, pp. 4-43, 2013.

- Metodo democratico e metodo scientifico nel rapporto fra diritto penale e politica. Rivista Italiana di Diritto e Procedura Penale, Milão, v. 44, n. 1, pp. 27-55, 2001.

DRESSLER, Joshua. Criminal law. $7^{\mathrm{a}}$ ed. São Francisco: LexisNexis, 2015.

DUBBER, Markus D. Policing possession: the war on crime and the end of criminal law. Journal of Criminal Law and Criminology, Chicago, v. 91, pp. 831-994, 2001.

DWORKIN, Gerald. Paternalismo. Trad. João Paulo Martinelli. Revista Justiça e Sistema Criminal, Curitiba, v. 1, n. 1, pp. 7-27, 2009.

DWORKIN, Ronald. Levando os direitos a sério. Trad. Nelson Boeira. São Paulo: Martins Fontes, 2002.

EAGLETON, Terry. As ilusões do pós-modernismo. Trad. Elizabeth Barbosa. Rio de Janeiro: Zahar, 1998.

EHRLICH, Eugen. Fundamentos da sociologia do direito. Trad. René Ernani Gertz. Brasília: UnB, 1986.

EL HIRECHE, Gamil Föppel e FIGUEIREDO, Rudá Santos. Crítica às tipificações relativas ao tratamento do "crime organizado" no projeto de código penal e na lei 12.850/2003. In: BADARÓ, Gustavo Henrique. Doutrinas essenciais: direito penal e processo penal. Vol. VI. São Paulo: Revista dos Tribunais, pp. 427-474, 2015.

ESTADOS UNIDOS DA AMÉRICA. Código Penal modelo. Disponível em http://www.icla.up.ac.za/images/un/use-of-force/western-europeothers/UnitedStatesofAmerica/Model $\% 20$ Penal $\% 20$ Code $\% 20$ United $\% 20$ States $\% 20 \mathrm{of} \% 20$ America\%201962.pdf. Acesso em 26.01.2018. 
ESTADOS UNIDOS DA AMÉRICA. Federal Rules of Criminal Procedure. Disponível em http://www.uscourts.gov/sites/default/files/federal_rules/FRCrP12.1.2014.pdf. Acesso em 15.02 .2018

ESTELLITA, Heloísa. Direito penal, constituição e princípio da proporcionalidade. Boletim IBCCRIM, São Paulo, v. 13, pp. 11-13, 2003.

FEIJÓO SANCHEZ, Bernardo José. Cuestiones básicas de los delitos de peligro abstrato y concreto en relación con el transito. Revista Ibero-Americana de Ciencias Penales, n. 1, pp. 150-181, 2000.

. Sobre a "administrativização" do direito penal na "sociedade do risco". Notas sobre a política criminal no início do século XXI. Trad. Bruna Abranches Arthidoro de Castro. Revista Liberdades, São Paulo, n. 7, pp. 23-61, 2011.

FEINBERG, Joel. Harm to others: the moral limits of the criminal law. Vol. I. Nova Iorque: Oxford, 1985.

FERRAJOLI, Luigi. A soberania no mundo moderno: nascimento e crise do estado nacional. Trad. Carlo Corccioli e Márcio Lauria Filho. São Paulo: Martins Fontes, 2002.

Derechos y garantias: la ley del más débil. Trad. Perfecto Andrés Ibañez e Andrea Greppi. Madrid: Trota, 1999.

FERREIRA, Carolina Costa. O estudo de impacto legislativo como possivel estratégia de contenção do encarceramento em massa no Brasil. Revista Brasileira de Ciências Criminais, São Paulo, v. 25, n. 129, pp. 137-180, 2017.

FERREIRA FILHO, Manoel Gonçalves. O estado no limiar do novo século. Revista Jurídica da Universidade de Franca n. 3, vol. 2, pp. 153-164, 1999.

. Princípios fundamentais do direito constitucional. 4a ed. São Paulo: Saraiva, 2015.

FEUERBACH, Paul Johann Anselm Ritter von. Tratado de derecho penal. Trad. Eugenio Raúl Zaffaroni e Irma Hagemeier. Buenos Aires: Hammurabi, 2007.

FIORE, Carlo. Il principio di offensività. L'indice penale, Padova, v. 28, n. 2, pp. 275-288, 1994.

FRANCO, Alberto Silva. Crimes hediondos. $5^{\mathrm{a}}$ ed. São Paulo: Revista dos Tribunais, 2005.

. Do princípio da intervenção mínima ao princípio da máxima intervenção.

Revista Portuguesa de Ciência Criminal, Coimbra, n. 2, v. 6, pp. 175-187, 1996.

FREITAS, Marcio Luiz Coelho. Proporcionalidade, bem jurídico e tutela penal do meio ambiente. Porto Alegre: Livraria do Advogado, 2015. 
FRIEDMAN, Lawrence. Law in america: a short history. Nova Iorque: A Modern Library, 2002 .

FUZIGER, Rodrigo. Direito penal simbólico. Curitiba: Juruá, 2015.

GALLOWAY, Russel W. Means-end scrutiny in american constitutional law. Loyola of Los Angeles Law Review, v. 1, pp. 449-496, 1998.

GALVÃO, Jorge Octávio Lavocat. O neoconstitucionalismo e o fim do estado de direito. São Paulo: Saraiva, 2014.

GASPARINI, Alessandro. Dall'indeterminate sentence alle sentencing guidelines: una riforma rivoluzionaria negli USA. L’indice Penale, Padova, v. 28, pp. 36-64, 1994.

GIDDENS, Anthony. As consequências da modernidade. Trad. Raul Fiker. São Paulo: UNESP, 1991.

GLOECKNER, Ricardo Jacobsen; RAMOS, Marcelo Buttelli. O respeito agonístico como princípio de legitimação (substancial) da racionalidade legislativa aplicada à produção de normas penais. Revista Brasileira de Ciências Criminais, São Paulo, v. 26, n. 147, pp. 779$811,2018$.

GOMES, Mariângela Gama de Magalhães. A importância dos critérios de seleção de crimes e cominação de penas. In: Instituto Brasileiro de Ciências Criminais et al. Belo Horizonte: D’Plácido, pp. 235-247, 2017.

- A lei 11.923/09 e outra vez a desproporcionalidade no ordenamento jurídico penal. Boletim IBCCRIM, São Paulo, ano 17, n. 199, pp. 8-9, 2009.

. O princípio da proporcionalidade no direito penal. São Paulo: Revista dos Tribunais, 2003.

. Periculosidade no direito penal contemporâneo. In: MENDES, Gilmar Ferreira; BOTTINI, Pierpaolo Cruz e PACELLI, Eugenio. Direito penal contemporâneo: questões controvertidas. São Paulo: Saraiva, pp. 237-253, 2011.

GONÇALVES, Carlos Roberto. Responsabilidade civil. $7^{\text {a }}$ ed. São Paulo: Saraiva, 2002.

GONZÁLES-SALAS CAMPOS, Raúl. La teoría del bien jurídico en el derecho penal. México: Pereznieto Ed., 1995.

GRACIA MARTÍN, Luis. A modernização do direito penal como exigência da realização do postulado do estado de direito (social e democrático). Trad. Érika Mendes de Carvalho. Revista Brasileira de Ciências Criminais, São Paulo, n. 88, pp. 95-142, 2011.

GRAMSCI, Antonio. Cadernos-seleções de notas de prisão. Trad. Carlos Nelson Coutinho. Rio de Janeiro: Paz e Terra, 1971. 
GRECO, Luís. As razões do direito penal: quatro estudos. Trad. coord. Eduardo Viana, Lucas Montenegro e Orlandino Gleizer. São Paulo: Marcial Pons, 2019.

Breves reflexões sobre os princípios da proteção de bens jurídicos e da subsidiariedade no direito penal. Revista Jurídica do Ministério Público de Mato Grosso, Cuiabá, v. 2, n. 3, pp. 249-276, 2007.

. Introdução à dogmática funcionalista do delito. Revista Brasileira de Ciências Criminais, São Paulo, n. 32, v. 8, pp. 307-362, 2000.

- Modernização do direito penal, bens jurídicos coletivos e crimes de perigo abstrato. Rio de Janeiro: Lumen Juris, 2011.

. Princípio da ofensividade e crimes de perigo abstrato: uma introdução ao debate sobre o bem jurídico e as estruturas do delito. Revista Brasileira de Ciências Criminais, São Paulo, n. 49, v. 12, pp. 89-147, 2004.

GRECO, Rogério. Adendo. Lei 12.015/2009: Dos crimes contra a dignidade sexual. Vol. I. 3 a ed. Niterói: Impetus, 2002.

GUASTINI, Riccardo. Teoría e ideologia de la interpretación constitucional. Madrid: Trotta, 2008.

GUERRA FILHO, Willis Santiago. Dignidade humana, princípio da proporcionalidade e teoria dos direitos fundamentais, pp. 305-319. In: MIRANDA, Jorge e SILVA, Marco Antônio Marques da. Tratado luso-brasileiro da dignidade humana. $2^{\text {a }}$ ed. São Paulo: Quartier Latin, 2009.

GÜNTHER, Klaus. De la vulneración de un derecho a la infración de un deber: ¿un cambio de paradigma en el derecho penal? In: La insostenible situación del derecho penal. Granada: Comares, pp. 489-505, 2000.

HABERMAS, Jürgen. Facticidad y validez: sobre el derecho y el estado democrático de derecho en términos de de teoría del discurso. Trad. Manuel Jiménez Redondo. $4^{\mathrm{a}}$ ed. Madrid: Trotta, 2005.

HARCOURT, Bernard E. The collapse of the harm principle. The Journal of Criminal Law and Criminology, Chicago, vol. 90, pp. 109-194, 1999.

HARVEY, David. Condição pós-moderna. Trad. Adail Ubirajara Sobral e Maria Stela Gonçalves. 17a ed. São Paulo: Loyola, 2008.

HASSEMER, Winfried. Derecho penal simbólico y protección de bienes jurídicos. Trad. Elena Larrauri. Revista Hispano-latinoamericana Pena y Estado, Barcelona, n. 1, pp. 23-36, 1991. 
. Direito penal libertário. Trad. Regina Greve. Belo Horizonte: Del Rey, 2007.

. Introdução aos fundamentos do direito penal. Trad. Pablo Rodrigo Auflen da Silva. Porto Alegre: safE, 2005.

. Linhas gerais de uma teoria pessoal do bem jurídico. In: GRECO, Luís e TÓRTIMA, Fernanda Lara (orgs.). O bem jurídico como limitação do poder estatal de incriminar? Rio de Janeiro: Lumen Juris, 2011.

- ¿Por qué castigar? Razones por las que merece la pena la pena. Trad. Manuel Cancio Meliá e Francisco Muñoz Conde. Valencia: Tirant lo blanch, 2016.

HEFENDEHL, Roland. O bem jurídico como a pedra angular da norma penal. In: GRECO, Luís e TÓRTIMA, Fernanda Lara (orgs.). O bem jurídico como limitação do poder estatal de incriminar? Rio de Janeiro: Lumen Juris, 2011.

HERNÁNDEZ, Moisés Moreno. Política criminal, sistema procesal penal y dogmática penal. In: GRECO, Luís e MARTINS, Antônio (org.). Direito penal como crítica da pena: estudos em homenagem a Juarez Tavares por ocasião de seu $70^{\circ}$ aniversário em 2 de setembro de 2012. Madrid: Marcial Pons, pp. 417-436, 2012.

HERZOG, Felix. Límites al control penal de los riesgos sociales: una perspectiva crítica ante el derecho penal en peligro. Trad. Elena Larrauri Puoan e Fernando Pérez Álvarez. Anuario de Derecho Penal y Ciencias Penales, n. 1, v. 46, pp. 317-327, 1993.

HESSE, Konrad. Elementos de direito constitucional da República Federal da Alemanha. Trad. Luís Afonso Heck. Porto Alegre: safE, 1998.

HIRSCH, Andrew von; WOHLERS, Wolfgang. Teoría del bien jurídico y estrutura del delito. Sobre los criterios de una imputación justa. In: HEFENDEHL, Roland; HIRSCH, Andrew von e WOHLERS, Wolfgang (eds.). La teoría del bien jurídico ¿Fundamento de legitimación del derecho penal o juego de abalorios dogmático? Madrid: Marcial Pons, pp. 279-302, 2016.

HOBSBAWN, Eric. Globalização, democracia e terrorismo. Trad. José Viegas. São Paulo: Companhia das Letras, 2007.

HÖFFE, Otfried ¿Existe un derecho penal intercultural? Um ensayo filosófico. Trad. Maximiliano Vaccalluzzo e Florencia Ham. Revista de Derecho Penal, n. 1, pp. 257-272, 2010.

HOLANDA, Sérgio Buarque. Raízes do Brasil. São Paulo: Companhia das Letras, 2009.

HORDER, Jeremy. Ashworth's principles of criminal law. $8^{\mathrm{a}}$ ed. Nova Iorque: Oxford University Press, 2016. 
HUBBART, Phillip. Making sense of search and seizure law: a fourth ammendment handbook. Durham: Carolina Academic Press, 2005.

HUDSON, Barbara. Justice through punishment: a critique of the "justice" model of correction. London: Macmillan, 1987.

HUSAK, Douglas. Crimes outside the core. Tulsa Law Review, v. 39, pp. 755-779, 2004. . Overcriminalization: the limits of the criminal law. Nova Iorque: Oxford, 2008.

IRTI, Natalino. L'età della decodificazione. Milano: Giuffrè, 1999.

JAKOBS, Günther. Derecho penal - parte general. Trad. Joaquin Contreras e José Luis S. Gonzales de Murillo. 2a ed. Madrid: Marcial Pons, 1997.

- ¿Qué protege el derecho penal: bienes jurídicos o la vigencia de la norma? Trad. Manuel Cancio Meliá. Cuadernos de doctrina y jurisprudencia penal, n. 11, v. 7, pp. 23-42, 2001.

JESSUP, Philip. Transational law. New Haven: Yale University Press, 1965.

JESUS, Damásio E. de. Direito penal: parte geral. Vol. I. 26ª ed. São Paulo: Saraiva, 2003.

JOFFILY, Tiago. O resultado como fundamento do injusto penal. Florianópolis: Empório do Direito, 2016.

JOWELL, Jeffrey. Beyond the rule of law: towards constitutional judicial review, Jowell JL, pp. 671-683, 2000.

JULIANO, Mario Alberto. La indefectible natureleza indicativa de los mínimos de las escalas penales. Pensamiento penal del sur, Buenos Aires, v. 1, pp. 485-503, 2004.

KAHLO, Michael. Sobre la relación entre el concepto de bien jurídico y la imputación objetiva en derecho penal. In: HEFENDEHL, Roland (ed.). La teoria del bien jurídico Fundamento de legitimación del Derecho penal o juego de abalorios dogmatico? Madri, Barcelona: Marcial Pons, 2007.

KANT, Immanuel. Fundamentação da metafísica dos costumes. Trad. Paulo Quintela. Lisboa: Edições 70, 1995.

KAUFMANN, Arthur. Filosofia do direito. Trad. António Ulisses Cortês. 3a ed. Lisboa: Fundação Calouste Gulbenkian, 2009.

KELSEN, Hans. Teoria pura do direito. Trad. João Baptista Machado. $4^{\mathrm{a}}$ ed. São Paulo: Martins Fontes, 2000. 
KINDHÄUSER, Urs. A dogmática jurídico-penal alemã entre a adaptação e a autofirmação: controle de limites da política criminal pela dogmática? Trad. Beatriz Corrêa Camargo e Wagner Marteleto Filho. Revista Brasileira de Ciências Criminais, São Paulo, v. 27, n. 155, pp. 214-225, 2019.

. Teoría de las normas y sistemática del delito. Lima: Ara, 2008.

KÖLER, Michael. O conceito de pena. Trad. Oliveiros Guanais. In: BADARÓ, Gustavo Henrique. Doutrinas essenciais: direito penal e processo penal. Vol. I. São Paulo: Revista dos Tribunais, pp. 319-349, 2015.

KUHLEN, Lothar. Der Handlungserfolg der strafbaren Gewässerverunreinigung (§ 324 StGB). Goltdammer's Archiv für Strafrecht, Heidelberg, ano 133, pp. 389-408, 1986.

. Umweltsfrecht - auf der Suche nach einer neuen Dogmatik. Zeitschrift für die Gesamte Strafrechtswissenschaft, Walter de Gruyter, Berlin, pp. 697-726, 1993.

LAMO DE ESPINOSA, Emilio. De bruces com la postmodernidad. Ignorancia, poder y comunicación en la sociedad del riesgo. Política exterior, vol. XV, n. 80, pp. 11-20, 2001.

LANZI, Alessio. Considerazioni sull'eventualità di un sindacato di ragionevolezza sulle scelte politico-criminale. L'indice Penale, Padova, v. 6, n. 3, pp. 895-903, 2003.

LARENZ, Karl. Metodologia da ciência do direito. Trad. José Lamego. $2^{\mathrm{a}}$ ed. Lisboa: Fundação Calouste Gulbenkian, 1989.

LASCÚRIAN SÁNCHEZ, Juan Antonio. La proporcionalidad de la norma penal. Revista Ibero-americana de Ciencias Penales, Porto Alegre, v. 1, n. 0, pp. 223-250, 2000.

LIMA, Alberto Jorge Correia de Barros. Direito penal constitucional: a imposição dos princípios constitucionais. São Paulo: Saraiva, 2012.

LIRA, Cláudio Rogério Sousa. Direito penal na pós-modernidade: a racionalidade legislativa para uma sociedade de risco. Curitiba: Juruá, 2015.

LISZT, Franz von. Tratado de direito penal alemão. Vol. I. Trad. José Hygino Duarte Pereira. Brasília: Senado Federal, Conselho Editorial: Superior Tribunal de Justiça, 2006.

LOBATO, José Danilo Tavares. Panorama dos crimes de posse. Revista Liberdades, São Paulo, n. 12, pp. 104-128, 2013.

LOCKE, John. In: Os grandes filósofos do direito. São Paulo: Martins Fontes, 2002.

LÓPEZ RUIZ, Francisco. Regla formal de justicia, valores y princípios. Derechos y libertades: Revista del Filosofia del Derecho y Derechos Humanos, Madrid, n. 4, v. 2, pp. 225-242, 1995. 
LYRA, José Francisco Dias da Costa. A moderna sociedade do risco e o uso politico do controle penal ou a alopoiesis do direito penal. Revista Brasileira de Ciências Criminais, São Paulo, n. 95, v. 20, pp. 239-272, 2012.

LUHMANN, Niklas. El derecho de la sociedad. Trad. Javier Torres Nafarrete. $2^{\mathrm{a}}$ ed. México: Universidade Iberoamericana, 2006.

; NAFARRETE, Javier Torres. Introducción a la teoria de sistemas: lecciones publicadas por Javier Torres Nafarrete. Mexico: Antropos, 1999.

. Sociologia del riesgo. Trad. Javier Torres Nafarrete. Guadalaraja: Universidad de Guadalaraja, 1992.

LUISI, Luiz. Um discurso sedicioso: a minimização do direito penal. Discursos sediciosos: crime, direito e sociedade. Rio de Janeiro, v. 1, n. 2, pp. 35-43, 1996.

LUNA, Eric. The overcriminalization phenomenon. American University Law Review, v. 54, n. 3, 2005.

MACHADO, Fábio Guedes de Paula. A leitura italiana sobre o principio da ofensividade. In: PASCHOAL, Janaína Conceição; SILVEIRA, Renato de Mello Jorge (coord.). Livro homenagem a Miguel Reale Júnior. Rio de Janeiro: G/Z, pp. 177-189, 2014.

- Reflexos da pós-modernidade no direito penal. Revista da Associação Brasileira dos Professores de Ciências Penais, São Paulo, v. 9, n. 16, pp. 49-74, 2012.

MACHADO, Maíra Rocha. Internacionalização do direito penal. A gestão de problemas internacionais por meio do crime e da pena. São Paulo: Direito GV, 2004.

MAGNOLI, Demétrio. Globalização: estado nacional e espaço mundial. 9a ed. São Paulo: Moderna, 1997.

MALISKA, Marcos Augusto. In: CANOTILHO, José Joaquim; MENDES, Gilmar Ferreira e STRECK, Lênio Luiz. Comentários à constituição do Brasil. São Paulo: Saraiva, 2013.

- Estado e século XXI: a integração supranacional sob a ótica do direito constitucional. Rio de Janeiro: Renovar, 2006.

MAÑAS, Carlos Vico. O princípio da insignificância como excludente da tipicidade no direito penal. São Paulo: Saraiva, 1994.

MANES, Vittorio. Attualità e prospettive del giudizio di ragionevolezza in materia penale. Rivista Italiana di Diritto e Procedura Penale, v. 50, pp. 739-789, 2007.

- El principio de ofensividad, entre codificación y previsión constitucional. Revista Aranzadi de derecho y proceso penal, Pamplona, n. 9, pp. 99-113, 2003. 
MANTOVANI, Ferrando. Il principio di offensività nello schema di delega legislativa per un nuovo codice penale. Rivista Italiana di Diritto e Procedura Penale, Milão, v. 4, n. 2, pp. 313-337, 1997.

MARCUS, Jonathan. Model Penal Code Section 2.02(7) and Wilfull Blindness. The Yale Law Journal, v. 102, n. 8, pp. 2231-2257, 1993.

MARINONI, Luis Guilherme e ARENHART, Sérgio Cruz. Manual do processo de conhecimento. $5^{\mathrm{a}}$ ed. São Paulo: Revista dos Tribunais, 2006.

MARINUCCI, Giorgio; DOLCINI, Emilio. Diritto penale minimo e nuove forme di criminalità. Rivista Italiana di Diritto e Procedura Penale, Milão, v. 42, n. 3, pp. 802-820, 1999.

MARONNA, Cristiano Avila. O crime do art. 273 do Código Penal e o caso dos medicamentos fitoterápicos. In: SILVEIRA, Renato de Mello Jorge; SALVADOR NETTO, Alamiro Velludo e SOUZA. Luciano Anderson de. Direito penal na pós-modernidade. São Paulo: Quartier Latin, pp. 137-149, 2015.

MARQUES, Cláudia Lima. A crise científica do direito na pós-modernidade e seus reflexos na pesquisa. Revista da Associação dos Magistrados Brasileiros, Brasília, n. 6, v. 3, pp. 237 248, 1999.

MARQUES NETO, Floriano de Azevedo. Regulação estatal e autorregulação na economia contemporânea. Revista de Direito Público da Economia, n. 33, 2011. Disponível em file://C:/Users/tfilippo/Downloads/MARQUES\%20NETO\%252c\%20Floriano\%20A\%252 c\%20Regula\%C3\%A7\%C3\%A3o\%20e\%20Autorregula\%C3\%A7\%C3\%A3o\%20(2).pdf. Acesso em 24.01.2018.

MARQUES, Oswaldo Henrique Duek. Fundamentos da pena. $3^{\text {a }}$ ed. São Paulo: Martins Fontes, 2016.

MARTÍN, Adán Nieto. Un triángulo necessário: ciencia de la legislación, control constitucional de las leyes penales y legislación experimental. In: MARTÍN, Adán Nieto et al. Hacia una evaluación de las leyes penales. Madrid: Marcial Pons, pp. 407-443, 2016.

MARTINELLI, João Paulo Orsini; DE BEM, Leonardo Schmitt. Os atos preparatórios na nova lei “antiterrorismo”. Boletim IBCCRIM, São Paulo, v. 24, n. 284, pp. 11-12, 2016.

MARTÍNEZ-BUJÁN PÉREZ, Carlos. Algunas reflexiones sobre la moderna teoria del "Big Crunch"en la seleción de bienes jurídico-penales. In: Anuario da Faculdade de Direito da Universidade da Coruña, pp. 953-985, 2003.

MARTINEZ ESCAMILLA, Margarita. La imputación objetiva del resultado. Madrid: Edersa, 1992. 
MARTINÓN CANO, Gilberto. El bien jurídico como principio irrenunciable en el derecho penal del siglo XXI. Revista penal Mexico, Mexico, DF, n. 1, pp. 161-170, 2011.

MARTOS NÚÑEZ, Juan Antonio. El princípio de intervención mínima. Anuario de Derecho Penal y Ciencias Penales, Madrid, n. 40, v. 1, pp. 99-134, 1987.

MATA BARRANCO, Noberto Javier de la. Aspectos nucleares del concepto de proporcionalidad de la intervención penal. Anuario de Derecho Penal y Ciencias Penales, v. 60, pp. 165-204, 2004.

MEIRELLES, Hely Lopes. Direito administrativo brasileiro. $31^{\text {a }}$ ed. São Paulo: Malheiros, 2005.

MELlo, Celso Antônio Bandeira de. Conteúdo jurídico do princípio da igualdade. $3^{\mathrm{a}}$ ed. São Paulo: Malheiros, 2006.

MENDES, André Pacheco Teixeira. Por que o legislador quer aumentar penas?: populismo legislativo na Câmara dos Deputados. Análise das justificativas das proposições legislativas no período de 2006 a 2014. Belo Horizonte: Del Rey, 2019.

MENDES, Gilmar Ferreira; COELHO, Inocêncio Mártires e BRANCO, Paulo Gustavo Gonet. Curso de direito constitucional. 2a ed. São Paulo: Saraiva, 2008.

MENDOZA BUERGO, Blanca. El derecho penal en la sociedad del riesgo. Madrid: Civitas, 2001 .

MESSUTTI, Ana. La justicia deconstruida. Barcelona: Bellaterra, 2008.

MEZGER, Edmund. Decrecho penal: parte general. Trad. Rodríguez Muñoz. Buenos Aires: El foro, 1985.

MILL, Stuart. On liberty. Kitchner: Ontario, 2001.

MIR PUIG, Santiago. El derecho penal en el estado social y democratico de derecho. Barcelona: Ariel, 1994.

El principio de proporcionalidad como fundamento constitucional de limites materiales del derecho penal. In: MIR PUIG, Santiago e JIMÉNEZ, Joan J. Queralt. Constitución y princípios del derecho penal: algunas bases constitucionales. Valencia: Tirant lo Blanch, pp. 67-104, 2010.

. Función fundamentadora y función limitadora de la prevención general positiva. Anuario de Derecho Penal y Ciencias Penales, Madrid, v. 39, n. 1, pp. 49-58, 1986.

Introducción a las bases del derecho penal. Barcelona: PPU, 1976. 
MOCCIA, Sergio. A difícil relação entre norma e ciência penal na pós-modernidade. Trad. André Ribeiro Giamberardino. In: GRECO, Luís e MARTINS, Antônio (org.). Direito penal como crítica da pena: estudos em homenagem a Juarez Tavares por ocasião de seu $70^{\circ}$ aniversário em 2 de setembro de 2012. Madrid: Marcial Pons, pp. 405-416, 2012.

. Emergência e defesa dos direitos fundamentais. Revista Brasileira de Ciências Criminais, São Paulo, v. 7, n. 25. pp. 58-91, 1999.

. La perene emergenza: tendenze autoritarie nel sistema penale. $2^{\mathrm{a}}$ ed. Napoli: Scientifiche Italiane, 1997.

MORAES, Alexandre de. Constituição do Brasil interpretada e legislação constitucional. São Paulo: Atlas, 2007.

MORENO LÓPEZ, María Soledad. La proporción de las penas a los delitos en la reciente reforma penal. Revista Brasileira de Ciências Criminais, São Paulo, n. 85, v. 18, 2010.

MORSELLI, Elio. La prevenzione generale integratrice nella moderna prospettiva retribuzionistica. Rivista Italiana di Diritto e Procedura Penale, Milão, v. 31, pp. 48-78, 1998.

MOURULLO, Gonzalo Rodriguéz. Delito y pena en la jurisprudencia constitucional. Madrid: Civitas, 2002.

NERY JUNIOR, Nelson. Princípios do processo civil na Constituição federal. 8a ed. São Paulo: Revista dos Tribunais, 2004.

NEUMANN, Ulfrid. El principio de proporcionalidad como principio limitador de la pena. Trad. Pablo Sánchez-Ostiz. In: ROBLES PLANAS, Ricardo (org.). Limites al derecho penal: principios operativos en la fundamentación del castigo. Barcelona: Atelier, pp. 201212, 2012.

NEVES, Marcelo. A constituição simbólica. São Paulo: Martins Fontes, 2007.

NIETO MARTÍN, Adán. Americanización o europeización del derecho penal económico. Revista Penal Tirant lo Blanch, Valencia, n. 19, pp. 120-136, 2007.

NIÑO, Luis Fernando. Politicas criminales y penales regresivas en el marco de la denominada "sociedad del riesgo". Revista de Derecho Penal: Fundación de Cultura Universitaria, Montevideo, n. 3, v. 21, pp. 25-40, 2013.

NORONHA, E. Magalhães. Direito penal. Vol. IV. São Paulo: Saraiva, 1988.

NOWAK, John E. e ROTUNDA, Ronald D. Constitutional law. $7^{\text {a }}$ ed. Illinois: Thomson and West, 2004. 
NOVOA MONREAL, Eduardo. La evolución del derecho penal en el presente siglo. Caracas: Editorial Juridica Venezolana, 1977.

NUCCI, Guilherme de Souza. Código penal comentado. $18^{\mathrm{a}}$ ed. Rio de Janeiro: Forense, 2017.

NUVOLONE, Pietro. Norme penali e principi costituzionale. Milão: Giuffrè, 1957.

OLIVEIRA, Liziane Paixão Silva. O conceito de soberania perante a globalização. Revista CEJ, Brasília, n. 32, v. 10, pp. 80-88, 2006.

ORTH, John V. Due process of law. Kansas: University Press, 2003.

OST, François. O tempo do direito. Trad. Maria Fernanda Oliveira. Lisboa: Piaget, 1999.

PACELLI, Eugênio. Curso de processo penal. 16ª ed. São Paulo: Atlas, 2012.

PADOVANI, Tullio. La disintegrazione attuale del sistema sanzionatorio e le prospettive di reforma: il problema della comminatoria edittale. Rivista Italina di Diritto e Procedura Penale, Milão, 1992.

PAGLIARO, Antônio; COSTA JÚNIOR, Paulo José. Dos crimes contra a administração pública. $2^{\mathrm{a}}$ ed. São Paulo: Malheiros, 1999.

PALAZZO, Francesco. Meritti e limitti dell'offensività. In: ANGIONI, Francesco et al. Prospettive di riforma del codice penale e valori costituzionali. Milão: Giuffrè, 1996.

- Offensività e ragionevolezza nel controllo di costituzionalità sul contenuto delle leggi penali. Rivista Italiana di Diritto e Procedura Penale, Milão, v. 41, pp. 350-384, 1998.

. Valores constitucionais e direito penal. Trad. Gérson Pereira dos Santos. Porto Alegre: Livraria do Advogado, 1989.

PAPA, Michele. Considerazioni sul controllo di costituzionalità relativamente alla misura edittale delle pene in Italia e negli USA. Rivista Italiana di Diritto e Procedura Penale, Milão, v. 27, pp. 726-758, 1984.

PAREDES CASTAÑÓN, José Manuel. Los delitos de peligro como técnica de incriminación en el derecho penal económico: bases político-criminales. Revista de Derecho Penal y Criminología, Madrid, n. 11, 2003.

PASCHOAL, Janaína Conceição. Constituição, criminalização e direito penal mínimo. São Paulo: Revista dos Tribunais, 2003.

PASTOR MUÑOZ, Nuria. Los delitos de posesión y los delitos de estatus: una aproximación político-criminal y dogmática. Barcelona: Atelier, 2005. 
PÉREZ CEPEDA, Ana Isabel. La seguridad como fundamento de la deriva del derecho penal postmoderno. Madrid: Iustel, 2007.

PIMENTEL, Manoel Pedro. O crime e a pena na atualidade. São Paulo: Revista dos Tribunais, 1983.

PIOVESAN, Flávia. Temas de direitos humanos. $6^{\text {a }}$ ed. São Paulo: Saraiva, 2013.

POLAINO NAVARRETE, Miguel. El injusto de la tentativa en el ejemplo de los delitos de mera actividad y de omissión pura, Cuardenos de Conferencias y Articulos, Universidad Externado de Colombia, n. 32, 2004.

PORTILLA CONTRERAS, Guillermo. Principio de intervención mínima y bienes jurídicos colectivos. Cuadernos de Política Criminal, Madrid, n. 39, pp. 723-748, 1989.

PRADO, Luiz Regis. Comentários ao código penal. 10 $0^{\mathrm{a}}$ ed. São Paulo: Revista dos Tribunais, 2015.

. Curso de direito penal brasileiro. $5^{\mathrm{a}}$ ed. São Paulo: Revista dos Tribunais, 2006.

. Direito penal do ambiente. São Paulo: Revista dos Tribunais, 2005.

. Teoria dos fins da pena: breves reflexões. In: BADARÓ, Gustavo Henrique. Doutrinas essenciais: direito penal e processo penal. Vol. I. São Paulo: Revista dos Tribunais, pp. 373-391, 2015.

PRITTWITZ, Cornelius. O direito penal entre o direito penal do risco e o direito penal do inimigo. Trad. Helga Sabotta de Araújo e Carina Cintra. Revista Brasileira de Ciências Criminais, São Paulo, n. 47, pp. 31-45, 2004.

QUIRÓS, Diego Zysman. Castigo e determinação da pena nos E.U.A.: um estudo sobre as United States Sentencing Guidelines. Trad. Jacson Zilio. Florianópolis: Empório do Direito, 2017.

RABELO, Galvão; VIANNA, Túlio. O fundamento constitucional do princípio da lesividade no direito brasileiro. Revista Brasileira de Ciências Criminais, São Paulo, n. 139, v. 26, pp. 69-108, 2018.

RAGUÉS I VALLÈS, Ramon. Whistleblowing: una aproximación desde el derecho penal. Madrid: Marcial Pons, 2013.

RAMÓN RIBAS, Eduardo. Interpretación extensiva y analogía en el derecho penal. Revista de Derecho Penal y criminología, Madrid, n. 12, pp. 111-164, 2014. 
RAMOS, Elival da Silva. A exigência da proporcionalidade no controle abstrato de normas brasileiro. Revista de Direitos Humanos Fundamentais, São Paulo, v. 1, n. 1, pp. 115-139, 2010 .

RAPOSO, Guilherme Guedes. Teoria do bem jurídico e estrutura do delito: uma reflexão sobre a legitimidade da antecipação da tutela penal como meio de proteção de bens jurídicos na sociedade contemporânea. Porto Alegre: Núria Fabris, 2011.

REALE JÚNIOR, Miguel. Instituições de direito penal: parte geral. $4^{\mathrm{a}}$ ed. São Paulo: Forense, 2012.

REZEK, José Francisco. Direito internacional público. São Paulo: Saraiva, 2000.

RICCARDI, Giuseppe. I confini mobili del principio di offensività. L'indice penale, Padova, v. 2, n. 2, pp. 711-739, 1999.

RICHTER, Jeremy W. e SANTOS, Paulo César Batista dos. Leis criminalizando o casamento entre negros e brancos nos Estados Unidos. In: ONODERA, Marcus Vinicius Kiyoshi e DE FILIPPO, Thiago Baldani Gomes. Brasil e EUA: temas de direito comparado. São Paulo: EPM, pp. 343-355, 2017.

ROBALDO, José Carlos de Oliveira. Controle difuso de constitucionalidade da norma penal: reflexões valorativas. São Paulo: Premier Máxima, 2008.

ROBLES PLANAS, Ricardo. A identidade da dogmática jurídico-penal. Trad. Marília Bassetto. In: BADARÓ, Gustavo Henrique. Doutrinas essenciais: direito penal e processo penal. Vol. II. São Paulo: Revista dos Tribunais, pp. 193-211, 2015.

ROCHA, Luiz Otávio de Oliveira. El principio de proporcionalidad y el control constitucional de las normas penales: el amparo a la mesa de Henri Batasuna. Cuadernos de Política Criminal, Madrid, n. 70, pp. 219-244, 2000.

ROMANO, Santi. O ordenamento jurídico. Trad. De Arno Del Ri Jr. Florianópolis: Fundação Boiteux, 2008.

ROMERO, Marta Muñoz de Morales. Codificación y técnica legislativa en Estados Unidos de América. In: MARTÍN, Adán Nieto et al. Hacia una evaluación de las leyes penales. Madrid: Marcial Pons , pp. 201-237, 2016.

ROSENFELD, Michel. Hacia una reconstrucción de la igualdad constitucional. Trad. Javier Dorado Porras. Derechos y libertades: Revista del Filosofia del Derecho y Derechos Humanos, Madrid.

ROTHENBURG, Walter Claudius. Princípios constitucionais. Porto Alegre: safE, 2003. 
ROXIN, Claus. A proteção de bens jurídicos como função do direito penal. André Luis Callegari e Nereu José Giacomolli (org. e trad.). $2^{\text {a }}$ ed. Porto Alegre: Livraria do Advogado, 2013.

. Derecho penal: parte general. Trad. Diego-Manuel Luzón Peña, Miguel Díaz y Garcia Conlledo, Javier de Vicente Remesal. Madrid: Civitas, 1997.

- ¿Es la protección de bienes jurídicos una finalidad del Derecho Penal? Trad. Iñigo Ortiz de Urbina Gimeno. In: In: HEFENDEHL, Roland; HIRSCH, Andrew von e WOHLERS, Wolfgang (eds.). La teoría del bien jurídico. ¿Fundamento de legitimación del derecho penal o juego de abalorios dogmático? Madrid: Marcial Pons, pp. 433-448, 2016.

. Estudos de direito penal. 2a ed. Trad. Luís Greco. Rio de Janeiro: Renovar, 2008.

. Novos estudos de direito penal. Trad. Luís Greco. LEITE, Alaor (org.). São Paulo: Marcial Pons, 2014.

Política criminal y sistema de derecho penal. Trad. Francisco Muñoz Conde.

Barcelona: Bosch, 1972.

Problemas actuales de dogmática penal. Trad. Manuel A. Abanto Vasquez.

Lima: Ara Editores, 2004.

. Problemas básicos de derecho penal. Trad. Diego Manuel Luzón Pena. Madrid:

Reus, 1976.

. Sobre a fundamentação político-criminal do sistema jurídico-penal. Trad. Luís Greco. Revista Brasileira de Ciências Criminais, São Paulo, n. 35, v. 9, pp. 13-27, 2001.

RUIVO, Marcelo Almeida. Legislação penal e ciências criminais: por uma teoria orientadora dos interesses político-criminais. Revista Brasileira de Ciências Criminais, São Paulo, v. 147, n. 26, pp. 587-614, 2018.

. Os crimes omissivos impróprios como delitos de violação de dever no nacionalsocialismo. Revista Brasileira de Ciências Criminais, São Paulo, n. 131, v. 25, pp. 223-247, 2017.

- Quatro diferenças cientificas fundamentais entre a criminologia e o direito penal. Revista Brasileira de Ciências Criminais, São Paulo, v. 137, n. 25, pp. 323-245, 2017.

SALVADOR NETTO, Alamiro Velludo. Direito penal e propriedade privada: a racionalidade do sistema penal na tutela do patrimônio. São Paulo: Atlas, 2014.

. Finalidades da pena: conceito material de delito e sistema penal integral. São Paulo: Quartier Latin, 2009. 
Responsabilidade penal da pessoa jurídica. São Paulo: Revistas dos Tribunais,

2018

. Tipicidade penal e sociedade de risco. São Paulo: Quartier Latin, 2006.

SÁNCHEZ-RUBIO, Ana. Igualdad y diferencia: ¿dos principios juridicos? Derechos y libertades: Revista del Filosofia del Derecho y Derechos Humanos, Madrid, v. 2, n. 4, pp. 259-285, 1995.

SANFELICE, José Luís. Pós-modernidade, globalização e educação. In: Globalização, pós-modernidade e educação. José Claudinei Lombardi (org.). Campinas: Autores Associados, 2001.

SANTAELLA, Lucia. O que é semiótica? São Paulo: Brasiliense, 2009.

SANTIAGO DANTAS, Francisco Clementino. Igualdade perante a lei e due process of law: contribuição ao estudo da limitação constitucional do poder legislativo. Revista Jurídica Virtual, Brasília, v. 3, n. 32, 2002. Disponível em https://revistajuridica.presidencia.gov.br/index.php/saj/article/viewFile/892/878. Acesso em 10.04.2018.

SANTOS, Boaventura de Sousa. A crítica da razão indolente: contra o desperdício da experiência. $8^{\mathrm{a}}$ ed. São Paulo: Cortez, 2011.

. Introdução a uma ciência pós-moderna. 4a ed. São Paulo: Graal, 1989.

. Um discurso sobre as ciências. 7a ed. São Paulo: Cortez, 2010.

; NUNES, João Arriscado. Reconhecer para libertar: os caminhos do cosmopolitismo cultural. Rio de Janeiro: Civilização Brasileira, 2003.

SANTOS, Daniel Leonhardt dos. Ofensividade e bem jurídico-penal: conceitos e fundamentos do modelo de crime como ofensa ao bem jurídico-penal. Revista Brasileira de Ciências Criminais, São Paulo, v. 24, n. 121, pp. 13-50, 2016.

SANTOS, Milton. Por uma outra globalização: do pensamento único à consciência universal. 10 ed. Rio de Janeiro: Record, 2003.

SARLET. Ingo Wolfgang. Constituição e proporcionalidade: o direito penal e os direitos fundamentais entre proibição de excesso e de insuficiência. Revista Brasileira de Ciências Criminais, São Paulo, v. 47, v. 12, pp. 60-122, 2004.

; VALE, André R. do. In: CANOTILHO, Joaquim José Gomes; MENDES, Gilmar Ferreira; SARLET, Ingo Wolfgang e STRECK, Lenio Luiz. Comentários à Constituição do Brasil. São Paulo: Saraiva, 2013. 
SAYRE, Francis Bowes. Public welfare offenses. Columbia Law Review, v. 33, n. 1, pp. 5588, 1993.

SCALCON, Raquel Lima. Breves reflexões sobre a racionalidade do processo legislativo e seu impacto na presunção e no controle de constitucionalidade da lei penal. In: D’ÁVILA, Fábio Roberto et al. Direito penal e constituição: diálogos entre Brasil e Portugal. Porto Alegre: Boutique Jurídica, pp. 393-407, 2018.

. Controle constitucional de leis penais: da prognose legislativa sobre os efeitos potenciais e concretos da lei penal aos deveres de seu monitoramento e de melhoria da lei penal. Rio de Janeiro: Lumen Juris, 2018.

SCHÜNEMANN, Bernd. Consideraciones críticas sobre la situación espiritual de la ciência jurídico-penal alemana. Trad. Manuel Cancio Meliá. Bogotá: Universidade Externado de Colombia, 1998.

. Direito penal, racionalidade e dogmática: sobre os limites invioláveis do direito penal e o papel da ciência jurídica na construção de um sistema penal racional. Adriano Teixeira (coord.). São Paulo: Marcial Pons, 2018.

. Do templo ao mercado. Como a justiça penal aparentemente transforma a teoria econômica do direito em prática, governo em governança e soberania em cooperação. Trad. Luís Greco. In: GRECO, Luís (coord.). Estudos de direito penal, direito processual penal e filosofia do direito. São Paulo: Marcial Pons, pp. 298-321, 2013.

. Espiral ou ovo estrelado? Modelos do direto: do modelo hermenêutico ao modelo da filosofia da linguagem. In: GRECO, Luís (org.). Estudos de direito penal, direito processual penal e filosofia do direito. São Paulo: Marcial Pons, pp. 285-297, 2013.

. O direito penal é a ultima ratio da proteção de bens jurídicos! - Sobre os limites invioláveis do direito penal em um Estado de Direito liberal. Trad. Luís Greco. In: SCHÜNEMANN, Bernd. Estudos de direito penal, direito processual penal e filosofia do direito. Luís Greco (coord.). São Paulo: Marcial Pons, pp. 69-90, 2013.

. Um olhar crítico ao modelo processual norte-americano. Trad. Danielle Soares Delgado Campos. In: GRECO, Luís (coord). Estudos de direito penal, direito processual penal e filosofia do direito. São Paulo: Marcial Pons, pp. 240-261, 2013.

SCHWABE, Jürgen. Cinquenta anos de jurisprudencia do Tribunal Constitucional Federal Alemão. Trad. Beatriz Hennig et al. Montevideo: Fundação Konrad-Adenaur, 2005.

SHECAIRA, Sérgio Salomão. Criminologia. $6^{\mathrm{a}}$ ed. São Paulo: Revista dos Tribunais, 2014.

SHIMIZU, Bruno; e CACICEDO, Patrick. Crítica à estipulação de critérios quantitativos objetivos para a diferenciação entre traficantes e usuários de drogas: reflexões a partir da perversidade do sistema penal em uma realidade marginal. Boletim IBCCRIM, São Paulo, n. 286, pp. 8-9, 2016. 
SILVA, Virgílio Afonso da. O proporcional e o razoável. Revista dos Tribunais, São Paulo, v. 798, pp. 23-50, 2002.

SILVA SÁNCHEZ, Jesús-Maria. Eficiência e direito penal. Trad. Antônio Ribeiro Lopes. Barueri-SP: Manole, 2004.

. El derecho penal ante la globalización y la integración supranacional. Revista Brasileira de Ciências Criminais, São Paulo, v. 6, n. 24, pp. 65-78, 1998.

La expansión del derecho penal: aspectos de la política criminal en las sociedades postindustriales. 3a ed. Madrid: Edisofer, 2011.

SILVEIRA, Fabiano Augusto Martins. O diálogo entre ciência e política no processo de formação das leis penais. Revista de informação legislativa - RIL, Brasília, v. 47, n. 186, p. 7-28, 2010.

SILVEIRA, Renato Jorge de Mello. A busca de legitimidade dos crimes de perigo abstrato no direito penal econômico. Boletim IBCCRIM, São Paulo, v. 20, n. 238, pp. 6-7, 2012.

. Crimes sexuais: bases críticas para a reforma do direito penal sexual. São Paulo: Quartier Latin, 2008.

; SAAD-DINIZ, Eduardo. Repatriação e crime: aspectos do binômio crise econômica e direito penal. Belo Horizonte: D’Plácido, 2017.

; SAAD-DINIZ, Eduardo. Compliance, direito penal e lei anticorrupção. São Paulo: Saraiva, 2015

SINGER, Richard e LA FOND, John. Criminal law. 3a ed. Nova Iorque: Aspen Publishers, 2004.

SOARES, Mário Lúcio Quintão. Teoria do estado: o substrato clássico como précompreensão para o direito constitucional. Belo Horizonte: Del Rey, 2001.

SOUZA, Luciano Anderson de. Expansão do direito penal e globalização. São Paulo: Quartier Latin, 2007.

Intervención jurídico penal y construcción de los delitos acumulativos. Revista de Derecho Penal Rubinzal-Culzoni, Buenos Aires, n. 1, pp. 379-405, 2013.

STAROBIN, Paul. After america: narratives for the next global age. Nova Iorque: Viking, 2001.

STEINMETZ, Wilson Antônio. Colisão de direitos fundamentais e princípio da proporcionalidade. Porto Alegre: Livraria do Advogado, 2001. 
STERNBERG-LIEBEN, Detlev. Bien jurídico, proporcionalidad y libertad del legislador penal. Trad. Íñigo Ortiz de Urbina Gimeno. In: HEFENDEHL, Roland; HIRSCH, Andrew von e WOHLERS, Wolfgang (eds.). La teoría del bien jurídico. ¿Fundamento de legitimación del derecho penal o juego de abalorios dogmático? Madrid: Marcial Pons, pp. 101-122, 2016.

STOCO, Tatiana de Oliveira. Personalidade do agente na fixação da pena. São Paulo: Revista dos Tribunais, 2014.

STRATENWERTH, Günther. Derecho penal: parte general I. El hecho punible. Trad. Manuel Cancio Meliá e Marcelo A. Sancinetti. Madrid: Thomson/Civitas, 2005.

STRAUSS, David. The living constitution. Nova Iorque: Oxford University Press, 2010.

STRUENSEE, Eberhard. Os crimes de posse. Trad. José Danilo Tavares Lobato. Revista Liberdades, São Paulo, n. 12, pp. 56-69, 2013.

STUCKENBERG, Carl-Friedrich. As deficiências constitucionais da teoria do bem jurídico. Trad. Lucas Minorelli. Revista Eletrônica de Direito Penal e Política Criminal (UFRGS), v. 2, n. 1, pp. 3-14, 2016.

SYDOW, Spencer Toth. O bem jurídico nos crimes informáticos. Revista Brasileira de Ciências Criminais, São Paulo, n. 113, pp. 193-212, 2015.

SZANIAWSKI, Elimar. Direitos de personalidade e sua tutela. $2^{\mathrm{a}}$ ed. São Paulo: Revista dos Tribunais, 2005.

TANGERINO, Davi de Paiva Costa. Culpabilidade. $2^{\mathrm{a}}$ ed. São Paulo: Saraiva, 2014.

TAVARES, Juarez. A crescente legislação penal e os discursos de emergência. Discursos sediciosos: Crime, Direito e Sociedade. Instituto Carioca de Criminologia, Rio de Janeiro, v. 2, n. 4, pp. 43-57, 1997.

. Bien jurídico y función en derecho penal. Trad. Monica Cuñarro. Buenos Aires: Hammurabi, 2004.

. Critérios de seleção de crimes e cominação de penas. Revista Brasileira de Ciências Criminais, São Paulo, número especial de lançamento, pp. 75-87, 1992.

. Fundamentos de teoria do delito. Florianópolis: Tirant lo Blanch, 2018.

Os objetos simbólicos da proibição: o que se desvenda a partir da presunção de evidência. Discursos sediciosos: Crime, Direito e Sociedade. Instituto Carioca de Criminologia, Rio de Janeiro, v. 17, pp. 89-99, 2012.

. Teoria do injusto penal. Belo Horizonte: Del Rey, 2000. 
. Teoria dos crimes omissivos. Madrid: Marcial Pons, 2012.

TEITEL, Ruti. Humanity's law. Oxford: Oxford University Press, 2011.

TEIXEIRA, Adriano. Teoria da aplicação da pena: fundamentos de uma determinação judicial da pena proporcional ao fato. São Paulo: Marcial Pons, 2015.

TERRADILLOS BASOCO, Juan María. Derecho penal de la empresa. Madrid: Trotta, 1995.

TEUBNER, Gunther. After legal instrumentalism? Strategic models of post-regulatory law. In: TEUBNER, Gunther (ed.). Dilemmas of law in the Welfare State. Berlin: De Gruyter, pp. 299-325, 1996.

THE BLUEBOOK: a uniform system of citation. Cambridge: The Harvard Law Review Association, 2007.

TIEDEMANN, Klaus. El concepto de delito económico y de derecho penal económico. Trad. Leopoldo H. Schiffrin. Revista de Derecho y Ciencias Penales n. 5-8, pp. 461-475, 1975.

La ley penal e blanco: concepto y cuestiones conexas. Trad. Antoni Llabrés Fuster. Revista Brasileira de Ciências Criminais, São Paulo, n. 37, v. 10, pp. 73-97, 2002.

TONRY, Michael. Sentencing matters. Nova Iorque: Oxford University Press, 1996.

TORRES, Igor Gonçalves. O enfraquecimento do estado nacional como entidade reguladora do comércio exterior. Dissertação de Mestrado. Universidade de Brasília, 1997.

TREIMAN, David M. Equal protection and fundamental rights - a judicial shell game. Tulsa Law Review, v. 15, pp. 183-229, 1979.

URQUIZO OLAECHEA, José. La prohibición de analogía in malam partem en el derecho penal. Revista Peruana de Ciencias Penales, Lima, n. 9, pp. 627-639, 1997.

VALOIS, Luís Carlos. O direito penal da guerra às drogas. $2^{\mathrm{a}}$ ed. Belo Horizonte: D’Plácido, 2017.

VARAT, Jonathan; AMAR, Vikram e COHEN, William. Constitutional law cases and materials. 13a ed. Nova Iorque: Foundation Press, 2009.

VIANNA, José Ricardo Alvarez. Considerações iniciais sobre semiótica jurídica. Revista CEJ, Brasília, v. 14, n. 51, pp. 115-124, 2010.

VIRILIO, Paul. A arte do motor. Trad. Paulo Roberto Pires. São Paulo: Liberdade, 1996. 
VOGEL, Joachim. La internacionalizacion del derecho penal y el proceso penal. Trad. Alfonso Galán Muñoz. Revista Penal Tirant lo Blanch, Valencia, n. 22, pp. 160-167, 2008.

WELZEL, Hans. O novo sistema jurídico-penal: uma introdução à doutrina finalista. $4^{\mathrm{a}} \mathrm{ed}$. Trad. Luiz Regis Prado. São Paulo: Revista dos Tribunais, 2001.

WILSON, James Q. Thinking about crime. Nova Iorque: Basic Books, 2003.

YACOBUCCI, Guillermo J. El sentido de los princípios penales: su naturaleza y funciones em la argumentación penal. Buenos Aires: Editorial Ábaco de Rodolfo Depalma, 1998.

ZAFFARONI, Eugenio Raúl. Em busca das penas perdidas. Trad. Vania Romano Pedrosa e Amir Lopez da Conceição. 5a ed. Rio de Janeiro: Revan, 2014.

. Globalización y sistema penal en America Latina: de la seguridad nacional a la urbana. Revista Brasileira de Ciências Criminais, São Paulo, n. 20, pp. 13-23, 1997

; ALAGIA, Alejandro; SLOKAR, Alejandro. Manual de derecho penal: parte general. 2a ed. Buenos Aires: Ediar, 2006.

; PIERANGELI, José Henrique. Manual de direito penal brasileiro. São Paulo: Revista dos Tribunais, 1997.

. O inimigo no direito penal. 2a ed. Trad. Sérgio Lamarão. Rio de Janeiro: Revan, 2007.

ZAGREBELSKY, Gustavo. El derecho dúctil. Madrid: Trotta, 2009. 